Araştırma Makalesi - Research Article

\title{
Türkiye'de Mekânsal Erişilebilirliği Sınırlayan Altyapı Eksikliklerinin Engelli İstihdamına Etkisi ${ }^{1}$
}

\section{The Impact of Infrastructure Deficiencies Limiting Spatial Accessibility on the Employment of Personswith Disabilities in Turkey}

\author{
Canan Öykü DÖNMEZ KARA* \\ (iD) 0000-0002-7825-3652
}

Sosyal Güvenlik Dergisi / Journal of Social Security

Cilt: 11 Sayi: 1 Y1l: 2021 / Volume: 11 Issue: 1 Year: 2021

Sayfa Aralığı: 117-140 / Pages: 117-140

DOI: $10.32331 /$ sgd.952558

\section{ÖZ}

Erişilebilirlik, farklı gereksinimleri bulunan kişilerin kendi başlarına evlerinden çıkabilmeleri, başkalarına ihtiyaç duymadan çeşitli binalara ve açık alanlara ulaşabilmeleri ve bunları kullanabilmeleri şeklinde tanımlanmaktadır. Engellilerin ekonomik, sosyal ve toplumsal hayata katılabilmeleri noktasında erişilebilirlik daha önemli hale gelmektedir. Bunun için başta devletin bir kısım yasal düzenlemeler hayata geçirmesi, sonra da yerel yönetimlerin yapılı çevrede ve kent ölçeğinde gereksinim duyulan tüm fiziksel, mimari ve altyapı önlemlerini almaları gerekmektedir. $\mathrm{Bu}$ çerçevede araştırmanın amacı, Türkiye'de mekânsal erişilebilirlik bağlamında engellilerin istihdamında karşılaşılan sorunların ortaya konulması ve bunların çözümüne yönelik bazı öneriler geliştirilmesidir. Araştırma, engelli dostu iller arasında sayılan Çanakkale ili kent merkezi ile sınırlandırılmıștır. Araştırma verileri görüşme yöntemiyle toplanmış, engelli derneklerinin yetkilileri ve engelli çalıştıran firmaların yetkilileriyle görüşmeler yapılmıştır. Veriler içerik analizi ile çözümlenmiştir. Sonuçta, her ne kadar engelli dostu iller arasinda sayılsa da Çanakkale kent merkezinde, mekânsal planlamanın engellileri hesaba katmayan bir anlayışla yapıldığı, bu durumun engellilerin kentsel hizmetlere ve iș imkânlarına erişimlerini sinırlandırdığ 1 görülmüştür.

Anahtar Sözcükler: Mekânsal erişilebilirlik, engelli, istihdam, belediye, Türkiye

\section{ABSTRACT}

Accessibility is defined as people with different needs to leave their homes on their own, reach and use various buildings and open spaces without the need for others. Accessibility becomes more critical for disabled people to participate in economic and social life. The purpose of the research is to reveal the problems encountered in the employment of disabled people in context of spatial accessibility in Turkey and to develop some suggestions for a solution. The research is limited to the city center of Çanakkale, which is considered among the disabled-friendly cities. The research data were collected by interview method, and interviews were held with the officials of the associations for the disabled and the representatives of the companies employing the disabled. The data were analyzed by content analysis. As a result, although it is counted among the disabledfriendly cities, it has been observed that the spatial planning in the city center of Çanakkale is done with an understanding that does not take the disabled persons into account, which limits the access of disabled people to urban services and job opportunities.

Keywords: Spatial accessibility, disabled, employment, municipality, Turkey

Önerilen atıf şekli: Dönmez Kara, C. Ö. (2021). Türkiye'de Mekânsal Erişilebilirliği Sınırlayan Altyapı Eksikliklerinin Engelli İstihdamına Etkisi. Sosyal Güvenlik Dergisi (Journal of Social Security). 11(1). 117-140

• Geliş Tarihi/Received: 29/03/2021 • Güncelleme Tarihi/Revised: 17/05/2021 • Kabul Tarihi/Accepted: 14/06/2021

\footnotetext{
${ }^{1} \mathrm{Bu}$ araştırma TAEM Uluslararası Sosyal Politika Kongresinde (18-20 Haziran 2019), özet bildiri şeklinde sunulmuştur.

* Doktor Öğretim Üyesi, Çanakkale Onsekiz Mart Üniversitesi, Biga İktisadi ve İdari Bilimler Fakültesi, Çalışma Ekonomisi ve Endüstri İlişkileri Bölümü, oykudonmez@comu.edu.tr
} 


\section{GíRIŞ}

Erişilebilirlik, kent sakinlerinin kent yönetimince sunulan imkânlardan eşit düzeyde yararlanmalarına olanak veren asgari altyapının sağlanması şeklinde tanımlanabilir. Kent sakinlerinin, yasalar önünde devlet ve yerel yönetimler tarafından verilen hizmet ve yardımlara eşit oranda katılma hakları bulunmasına karşın altyapı eksikliği kaynaklı sorunlar nedeniyle özellikle kentlerde yaşayan engelliler bu imkânlara erişimde sorunlarla karşılaşmaktadırlar. Bununla birlikte, engellilerin de diğer tüm insanlar gibi yaşamak, aile kurmak, toplumda bir işe yaradığını anlayarak psikolojik olarak kendilerini iyi hissetmeleri gibi nedenlerle çalışmaları gerekmektedir.

Çalışma, temel insan hakları arasında olup, 1982 Anayasası'nda da kabul edilmiş; devlet bu imkânı vatandaşlarına sunmakla yükümlü kılınmıştır. Modern toplumda iş olanakları kentlerde yoğunlaştığından ve nüfusun çok önemli bir kısmı da kentlerden yaşadığından insanların işlerine ulaşmaları başta toplu taşıma, kaldırımlar, yaya geçitleri, 1şıklar, binalar, park yerleri gibi altyapı imkânlarının sağlanmasına bağlıdır. Altyapının kentte yaşayan herkesin ihtiyacına eşit oranda cevap verecek düzeyde olmaması engellilerin iş yaşamına katılmasını oldukça zorlaştırmaktadır. İşverenler açısından ise işe aldıkları kişilerin tam saatinde işlerinin başında olması önemlidir. Ancak ulaşım ve altyapı eksiklikleri nedeniyle işverenlerin aklında engellilerin işlerine vaktinde gelmeleri konusunda güçlük yaşayacakları endişesi öne çıkmaktadır. Bununla birlikte, engelli çalıştırmaya ilişkin yükümlülük, devlet teşvikleri ve insani nedenlerle işverenler engellileri istihdam etmektedirler. Sonuçta temel insan hakları arasında sayılan çalışma hakkının engelliler için de yerine getirilmesinde, başta yasal düzenlemeler ve denetimler noktasında devlete, mevzuatta ön görülen altyapılı çevrenin oluşturulmasında ise belediyelere önemli görevler düşmektedir. Bunun yanında, engelli istihdamına katkı verme noktasında özel sektörün, engellilerin haklarının savunulması ve toplumda engelli haklarına ilişkin bilinç oluşturulması aşamasında sivil toplum kuruluşlarının rol üstlenmelerinin engelli istihdamı açısından önemli olduğu söylenebilir.

Araştırmanın ilk kısmında önce, kavramsal ve hukuksal çerçeve başlığg altında engellilik, erişilebilirlik, kavramları açıklanmış, uluslararası ve ulusal mevzuat incelenerek erişilebilirliğin hukuksal sınırları çizilmiştir. Sonrasında uluslararası ve ulusal literatürde engellilerin erişilebilirlikleri ve istihdamlarına ilişkin araştırmalar derlenmiş ve değerlendirilmiştir. İkinci kısımda yöntem başlığı altında problem ve araştırma soruları, amaç ve önem, kapsam ve sınırlılıklar, desen, geçerlilik ve güvenilirlik anlatılmıştır. Üçüncü kısımda araştırmada ulaşılan bulgular aktarılmış ve açıklanmıştır. Sonuç kısmında önce araştırma soruları değerlendirilmiş, sonrasında araştırma bulguları literatürdeki araştırma bulguları ile karşılaştırılmıştır. Sonra benzer konularda ileride yapılması muhtemel çalışmalar için önerilerde bulunulmuş; araştırma bulgularından kimlerin nasıl faydalanabileceği tartışılmıştır.

\section{I- KAVRAMSAL VE HUKUKSAL ÇERÇEVE}

Engelli kavramı Birleşmiş Milletler (BM) Genel Kurulu'nun 1975 yılında yayınladığı “Engelli Bireylerin Hakları Bildirgesi'nde tanımlanmıştır. Tanıma göre; engelli, normal bir bireyin kişisel ya da sosyal yaşantısında kendi kendisine yapması gereken işleri, bedensel veya ruhsal yeteneklerindeki kalıtsal ya da sonradan oluşan noksanlık sebebi ile yerine getirememesidir (UN, 1975: 88). Engellilik ise çağdaş yaklaşımlarda farklı şekillerde tanımlanan bir kavramdır.

Geleneksel yaklaşımda engellilik bireylerin fiziksel, duyusal ya da bilişsel bozukluklar sonucunda yaşadığı sorunlar çerçevesinde ele alınmıştır. Bu bağlamda kişilerin tedavisi için 
Türkiye'de Mekânsal Erişilebilirliği Sınırlayan Altyapı Eksikliklerinin Engelli İstihdamına Etkisi

tıbbi ve rehabilitasyon hizmetlerine erişimi veya karşılaştıkları sınırlılıkların telafi edilmesi için istihdam, evde bakım ve sosyal güvenlik gibi tedbirlerin alınmasına çalışılmıştır. Bir başka ifade ile engellilik bireysel açıdan ele alınmıştır (Priestley, 2012: 406). Geleneksel yaklaşım engelli bireylerin durumlarını sakatlığın ve hastalığın tıbbi açıklaması ile ele almışlar; engelli bireylerin yaşam alanlarına karşılaştıkları sosyal ve çevresel engellemeleri göz ardı etmişlerdir (Burcu, 2006: 63). Dünya Sağlık Örgütü (1980: 13-14), engellilik tanımını geleneksel yaklaşıma göre ele almıştır.

Dünya Sağlık Örgütü, birbirleri yerine kullanılan yetersizlik, özürlülük ve engellilik kavramlarını tanımlayarak kavram kargaşasını önlemeye çalışmıştır. Yetersizlik, Özürlülük ve Engelliliklerin Uluslararası Sınıflandırılması (International Classification of Impairments, DisabilitiesandHandicaps-ICIDH) sistemini geliştirilerek yetersizlik vücudun fiziksel, zihinsel veya işlevsel bozukluğu; özürlülük yetersizlik sonucunda günlük aktivitelerin gerçekleştirilmesinde yaşanan davranış ve fonksiyon eksikliği; engellilik ise yetersizliğin ya da özürlülüğün sonucunda toplumdaki kişiler tarafindan beklenen performans veya durumu gerçekleştirememe olarak tanımlanmıştır (WHO, 1980: 14). Dünya Sağlık Örgütü tarafından yapılan tanımlamada engellilik tanımı bireyin engellilik sebebi ile karşılaştığı yoksunluklara ve yetersizliklere yer vermemiş bir başka ifade ile sosyal boyutu ele alınmamıștır. $\mathrm{Bu}$ bağlamda 1980 sonrasında engellilik kavramı sosyal yaklaşım çerçevesinde farklı bir şekilde tanımlanmaya ve sınıflandırılmaya çalışılmıştır.

Dünya Sağlık Örgütü 2001 yılında İşlevsellik, Yetiyitimi ve Sağlığın Uluslararası Sinıflandırılması (International Classification of Functioning, DisabilityandHealth-ICF) sistemini geliştirmiş ve kullanmaya başlamıştır. ICF sisteminde bireyin engellilik durumunun sınıflandırılması yanında çevresel faktörler, sosyal ve günlük yaşama katılım, tarafsızlık ve toplumun diğer bireyleri ile eşit muamele görmelerini sağlayacak düzenlemeler getirilmiştir (WHO, 2001: 5).

Dünya Sağlık Örgütü’nün 1980 yılında oluşturduğu ICIDH sisteminde "hastalık sonuçları”, ICF (2001) tarafından "sağlık bileşenleri”"nin sınıflandırılmasına dönüştürülmüştür. Böylece engelliliğin sosyal yaklaşımlar ele alınarak sağlığın içeriği kapsamlı olarak tanımlanmış sağlık durumu veya hastalık sonucunda ortaya çıkan etkiler belirtilmiştir. ICF, sadece engelli bireyler için değil aynı zamanda tüm insanlarla ilgili evrensel bir sınıflandırmadır (Bilsin ve Başbakkal, 2014: 67).

Sosyal yaklaşıma göre engellilik kavramı bireyin kendi fizyolojik engelleri sebebi ile yaşadığı kısıtlılıklardan çok yaşadığı toplumdan kaynaklanan kısıtlılıklardan kaynaklanmaktadır. Örneğin felçli bir kişi hareket alanı kısıtlandığı için engellidir. O halde sosyal anlamda engellilik yalnızca hareketin yerine getirilememesi durumu değil, toplumun tekerlekli sandalye kullanan bu bireyin yaşamını kolaylaştırmak için rampalar, kaldırımlar, asansörler vb. sağlayamayarak diğer bireylerle yaşamasını engellemesi durumudur (Burcu, 2011: 39). Engellilik, bireyin fiziksel eksikliği sebebi ile yaşadığı toplumun bir parçası olmasından çok toplumun engelliliğe yüklediği damgalayıcı tutumdan kaynaklanan bir kavram olduğu ifade edilmektedir (Goffman, 1963: 14-15). Engellilik kavramı politik açıdan sosyal yaklaşımdaki şekli ile ele alınmaya başlamıştır. Bu bağlamda sosyal politikanın bir alanını oluşturmuştur. Türkiye'de de engellilik kavramı sosyal yaklaşım çerçevesinde tanımlanmaktadır.

Türk Dil Kurumu Sözlüğünde engellilik "vücudun eksik ya da kusurlu olması ve özürlülük durumu" şeklinde tanımlamaktadır (www.tdk.gov.tr, 2020). 2005 tarih ve 5378 sayılı Engelliler Hakkında Kanun'un 3/c bendinde engelliler; fiziksel, zihinsel, ruhsal ve duyusal açıdan çeşitli düzeylerde kayıpları olan ve bu nedenle topluma diğer bireyler ile birlikte eşit 
koşullarda tam ve etkin katılımını kısıtlayan tutum ve çevre koşullarından etkilenen bireyler olarak tanımlanmaktadır (RG: 07.07.2005/ 25868).

Engelliler, diğer kent sakinleriyle eşit oranda kentsel hizmetlere erişimde sorunlar yaşamaktadırlar. Oysa, kentsel hizmetler, kentte yaşayan tüm bireylerin eşit ve adil bir biçimde yararlanabildikleri hizmetler olmalıdır. Bu nedenle, kentlerin yaşanabilir mekânlar haline getirilmesinde, dezavantajlı gruplar arasında sayılan kadın, çocuk, engelli ve yaşlı bireylerin hareketlerini sınırlamayacak şekilde dizayn edilmiş sosyal ve fiziksel ortamlar şeklinde tasarlanmaları önem arz etmektedir (Bıçkı ve Diğerleri, 2016: 451). Engellilere yönelik ideal kent mekânlarının tasarlanması erişilebilirlik kavramı önemli kılmıştır. Erişilebilirlik; bir ürünün, hizmetin, teknolojinin ya da ortamın engelliler, yaşlılar ve çocuklar dâhil herkes tarafından ulaşılabilir ve kullanılabilir olma durumudur. Erişilebilirlik engelliler bakımından ele alındığında, onların başkalarına ihtiyaç duymadan evlerinden çıkabilmeleri, gitmek istedikleri yere rahatça ulaşabilmeleri ve çeşitli ürün ve hizmetleri kullanabilmelerini ifade etmektedir (Yılmaz ve Diğerleri, 2018: 538).

Şat ve Göver (2017: 533), Lefebvre tarafindan geliştirilen "kent hakkı" kavramının kent imkânlarından yararlanma ve kentle ilgili karar alma süreçlerine katılma hakkını ifade ettiğini, aynı zamanda, engellilerin de bu imkânlara erişebilmelerine dayanak teşkil ettiğini ifade etmişleridir. Engellilerin, kentli olmaktan kaynaklanan haklarını kullanabilmeleri ve yaşam kalitelerinin artırılması bakımından kent karmaşasında karşılaştıkları sorunları azaltacak mimari çözümler üretilmesi ve onların özel ihtiyaçlarına yönelik yasal düzenlemeler yapılması gerekmektedir. Lefebvre'ye göre kentsel hak, kentin ekonomik, sosyal ve politik ilişkilerinin devletten ayrı bir şekilde yeniden yapılandırılmasıdır. Bu bağlamda kentsel hak kavramında, kentle ilgili kararların kontrolünün tümüyle kent sakinlerine bırakılarak, kentsel mekânın üretiminin temellerini oluşturan güç ilişkilerinin değiştirilerek ihtiyaçların karşılanması üzerinde durulmaktadır. Harvey ise kentsel haklara erişim yanında bu hakların ihtiyaca göre değiştirilebilmesi hakkına vurgu yapmıştır (Güler, 2011: 52). Bu bağlamda, kent sakinlerinin, kentin sunduğu imkânlardan yararlanma haklarının yanı sıra bu hakların ihtiyaca göre iyileştirilmesi ya da değiştirilmesi haklarının da olduğu söylenebilir.

Engelsiz kent, herkes için erişilebilir kent olarak ifade edilmektedir. Diğer bir ifadeyle, kentte yaşayan gençler, yaşlılar, engelliler, kadınlar, çocukların yanı sıra kente ziyarete gelen herkesin yaşam kalitesini arttıracak ve hayatını kolaylaştıracak mekânların hizmetlerin sunulabilmesi anlamına gelmektedir. Kentlerin engelsiz ve erişilebilir kılınması fiziki planlamanın yanında, finansal, sosyal ve yönetsel iş birliklerini de gerekli kılmaktadır. Bu süreçte, toplumsal farkındalığın arttırılmasının da önemine değinilmektedir. Kentsel erişilebilirliği sınırlayan unsurların başında uygun olmayan zemin kaplamaları ve yüzeyler, güvenlik tedbiri olmadan yapılan alt yapı çalışmaları, uygun olmayan kaldırım ölçüleri ve rampalar, güvenliksiz kavşak noktaları ve yaya geçitleri, işaret ve uyarıcı levhaların ve aydınlatmanın eksikliği, kullanışsız kent mobilyaları ve sesli ve görsel uyarıcılardan yoksun ulaşım sistemi sayılmaktadır (Odabaş-Uslu ve Güneş, 2017: 31).

Engellilerin kentsel mekânlara ve hizmetlere erişimlerine ilişkin uluslararası ve ulusal bazı düzenlemeler yapılmıştır. Bu kapsamda, 2006'da BM Engellilerin Haklarına İlişkin Sözleşme (EHISS) yapılmış; Türkiye tarafından 2009'da onaylanmıştır. Sözleşme; fiziksel, zihinsel, ruhsal ve duyusal yetilerinde çeşitli düzeyde kayıplar olan ve topluma diğer bireyler ile eşit koşullarda tam ve etkin katılamayan bireyleri kapsamaktadır (md. 1). Aynı zamanda, engelli bireylerin toplumun diğer bireyleriyle eşit koşullarda fiziki çevreye, ulaşıma, bilgi ve iletişim olanaklarına, kırsal ve kentsel halka açık alanlara ve hizmetlere erişimlerinin sağlanması hüküm altına alınmıştır (md. 9)(RG: 14.07.2009/27288). 
EHIS'de erişilebilirlik, engelli bireylerin insan haklarından yararlanabilmeleri için ekonomik, sosyal, kültürel ve politik süreçlere katılımı şeklinde tanımlanmıştır. Sözleşmede engellilerle ilgili ilkeler belirlenmiş ve bu ilkelerin uygulayıcılara yol göstermesi amaçlamıştır. Kapsayıcı ve sürdürülebilir bir kentsel gelişim politikaları geliştirilirken, engellileri de içeren erişilebilir bir yaşam yaratmaya odaklanılmasının önemine değinilmiştir. Yaşamsal alanları erişilebilir kılmanın yolunun engelliliğe duyarlı yapılar, standartlar, planlamalar ve herkes için tasarım yaklaşımının benimsenmesi ile sağlanabileceği belirtilmiştir. Tasarım sürecine engelli bireylerin ve örgütlerin katılımının önemi vurgulanmaktadır. Kentlerin ulaşım, yapılı alan, yeterli konut, kamusal alanlar, tesisler, hizmetler, bilgi ve iletişim teknolojileri konularında da herkes için erişilebilir kılınması gerekmektedir. Engellilerin erişilebilirliklerinin sağlanması ve dışlanmışlık hislerinin ortadan kaldırılması için çok paydaşıı ve boyutlu çalışmalar yapılmasının önemine dikkat çekilmiştir. Bu bağlamda, BM öncülüğünde hazırlanan 2015'te "Dünyamızı Dönüştürmek: 2030 Sürdürülebilir Kalkınma Gündemi" ve 2016 Habitat III’te görüşülen "Yeni Kentsel Gündem"de engellilerin erişimine ilişkin evrensel bazı ilkelere yer verildiği belirtilmektedir (Erten ve Aktel, 2020: 902-903).

BM 2030 Sürdürülebilir Kalkınma Gündemi’nde herkesi kucaklayan, güvenli, güçlü ve sürdürülebilir kentler yaratmak (Hedef 11) tüm bireyler için erişilebilirliği arttırmaya yönelik düzenlemeleri hedeflemektedir. Hedef 11 'de kentlerin dünya nüfusunun yarısından fazlasının yaşadığ yaratmada katkıda bulunması vurgulanmaktadır (Ar ve Uğuz, 2017: 525-527). Sürdürülebilir Kalkınma Hedefleri’nde toplumun bütün fertlerinin erişilebilirliğinin sağlanmasına yönelik hedefler belirlenmiş, toplumun her kesimine eşit şekilde yaşam imkânlarının sağlanmasına çalışılmıştır.

Yeni Kentsel Gündem'de ise kentlerin ve yerleşmelerin planlamasından tasarımına, finansmanından imar, idare ve yönetim şekillerine kadar yeniden ele alınması gerektiği belirtilmiştir. Kentlerin yeniden yapılanması kapsamında eşitsizliklerin azaltılması gündeme getirilmiştir. Böylece insan sağlığı ve refahının iyileştirilmesine çalışılmaktadır (United Nations, 2017: 9). Böylece eşitsizlikleri azaltacak şekilde kent ve yerleşim planlamaları yapılarak engelli bireylerin erişimlerine katkıda bulunulabilecektir.

Engellilerin erişim haklarına ilişkin bir diğer önemli belge 1992 Avrupa Kentsel Şartı'dır. Avrupa Kentsel Şartı, Avrupa kentlerinde yaşayan vatandaşlara tanınması gereken asgari hakları sıralamaktadır. Taraf ülkelerin, yerel yönetimleri anlaşmada sayılan hakların dil, din, ırk, renk, cinsiyet, sosyal, ekonomik ve siyasal ayrım gözetilmeden ve fiziksel veya zihinsel engellerine bakılmadan herkese eşit şekilde uygulanmasıyla yükümlü kılınmıştır (https://rm.coe.int/2020). Avrupa Kentsel Şartı'nda “ideal kent", kentli haklarına saygıl1, orada yaşayanlara, ziyaret edenlere, çalışanlara, ticaret yapanlara, eğitim görenlere en iyi yaşam imkânlarını sunan, birçok sektör ve aktiviteyi uyum içinde bünyesinde barındıran yaşam alanı olarak tanımlanmıştır. Avrupa Kentsel Şartı'nda ulaşım, çevre, fiziki yapılar, tarihi kentsel yapı mirası, güvenlik, konut, spor, kültür, sağlık halk katılımı, ekonomik kalkınma ve engelliler ile ilgili ilkeler de yer almaktadır (Erten ve Aktel, 2020: 904; OdabaşUslu ve Güneş, 2017: 32). Engellilerle ilgili olarak, kentlerin, herkesin her yere erişebilirliğini sağlayacak şekilde tasarlanması gerektiği belirtilmiştir. Engellilerin toplumla bütünleştirilmesi ilkesini anlatan bölümde, engelli dernekleri arasında iş birliklerinin geliştirilmesi anlayıșı benimsenmiştir. Konutların ve işyerlerinin yanı sıra ulaşım ve iletişim kanallarının da engellilerin erişimine uygun şekilde düzenlenmesinin önemine dikkat çekilmiştir (www.mo.org.tr, 2020). 
Avrupa Birliği (AB), engelsiz kentleri önemsemekte ve 2010'dan beri AB üyesi ülkelerin çeşitli kentlerine "Erişilebilir Kent" ödülleri vermektedir. Erişilebilir kent ödüllerinde aday kentlerde yapılı çevre ve kamusal alanlar, ulaşıma ilişkin altyapı, iletişim, enformasyon ve kamusal servisler, etkinlikler alanları göz önünde bulundurulmaktadır. Kentler eylemlerin kapsamı, katılım ve sahiplenme derecesi, yaratılan etki, uygulama sonuçlarının niteliği ve sürdürülebilirliği, engelliler ve ilgili diğer grupların katılımı kategorilerinde değerlendirilmeye tabi tutulmaktadır (Erten ve Aktel, 2020: 907; Odabaş- Uslu ve Güneş, 2017: 32). Her yıl farklı kentlere verilen bu ödüllerle engelsiz kent algısının Avrupa Kentsel Şartı ilkelerine uygun olarak tüm Avrupa kentlerinde benimsenmesi ve teşvik edilmesi amaçlanmaktadır. Bu bağlamda, Birlik ülkelerinde ve aday ülkelerde mekânsal erişilebilirliğin iyileştirilmesinin sağlanmasına çalışıldığı söylenebilir.

Evrensel bir hak olarak kabul gören mekânsal erişilebilirlik konusunda Türkiye'de Avrupa standartlarına uyum sağlama noktasında çalışmakta, buna ilişkin yasa ve yönetmelikler çıkarmakta ve mevcut yasalarında mekânsal erişilebilirlik ve engellileri içeren düzenlemeler yapmaktadır. Türkiye'de engellilere yönelik kurumsallaşma süreci 1997'de Başbakanlık Özürlüler İdaresi Başkanlığının oluşturulması ile başlamıştır. Başkanlığın kurulmasından sonra 572 sayılı Kanun Hükmünde Kararname ile 3194 sayılı İmar Kanunu'nda² yapılan düzenleme ile fiziksel çevrenin engelliler için ulaşılabilir ve yaşanabilir kılınması için imar planlarının kentsel, sosyal ve altyapı alanlarında ve yapılarda Türk Standartları Enstitüsünün ilgili standartlarına uymaları gerektiği belirtilmiştir. 1999'da "Planlı Alanlar Tip İmar Yönetmeliği" ve "Plan Yapımına Ait Esaslara Dair Yönetmelik"lerle kentsel alanlarda altyapının Türk Standartlar Enstitüsünce belirlenen engellilere ilişkin standartlara göre düzenlenmesi istenmiştir. 2004 Toplu Taşıma Araçları Tip Onay Yönetmeliği'nde de "Hareket Engelli Yolcuların Araca Giriş-Çıkışlarını Kolaylaştıran Teknik Donanımla İlgili Şartlar”a araçlara onay verileceği belirtilmiştir (Bıçkı vd., 2016: 452).

2005 tarih ve 5378 sayılı Engelliler Hakkında Kanun'un 3/f bendinde erişilebilirlik "binaların, açık alanların, ulaşım ve bilgilendirme hizmetleri ile bilgi ve iletişim teknolojisinin engelliler tarafından güvenli ve bağımsız olarak ulaşılıp kullanılabilir" olması şeklinde tanımlanmıştır (RG: 07.07.2005/ 25868). Engelsiz bireylere göre tasarlanan kentsel alanlar çoğu zaman engelli bireyler için engel teşkil edebilmektedir. Engelli bireyler için kentin tüm alanlarına erişilebilirlik, insan olmanın getirdiği hakları kullanabilmenin bir aracı olmakla beraber bağımsız hareket edebilmenin ve toplumsal yaşama katılabilmenin de bir gereğidir. Bu nedenle engelli bireylerin de toplumun diğer bireyleri gibi fiziksel mekânlara, bilgiye, halka açık tüm tesislere ve hizmetlere ulaşımı önemlidir (Çağlar, 2012: 543). 5378 sayılı Kanun'da resmi yapılar, mevcut tüm yol, kaldırım, yaya geçidi, açık ve yeşil alanlar, spor alanları vb. sosyal ve kültürel alt yapı alanları ile gerçek ve tüzel kişiler tarafından yapılmış ve umuma açık hizmet veren her türlü yapıların kanunun yürürlüğe girdiği tarihten itibaren yedi yıl içinde engellilerin erişebilirliğine uygun hale getirilmesi zorunluluğu hükme bağlanmıştır. 5378 sayılı Kanun ile aynı zamanda belediyelere toplu taşıma hizmetlerini kanunun yürürlüğe girdiği tarihten itibaren yedi yıl ${ }^{3}$ içinde engellilerin erişebilirliğine uygun hale getirme zorunluluğu da getirmiştir (RG: 07.07.2005/ 25868 Geçici Madde 3). 2006/18 sayılı Başbakanlık Genelgesi ile yerel yönetimlerin 2005 yılında başlayan 7 yıllık süreçte satın alacakları, kiralayacakları veya denetimlerinde bulunan toplu taşıma araçlarının TSE'nin ilgili standartlarına uyularak engellilerin erişebilirliğine uygun hale getirmeleri gerektiği belirtilmiştir (RG: 12.07.2006/26226). 2011 tarihli Şehir içi Toplu Ulaşım

23194 Sayılı İmar Kanunu, R.G. 09.05.1985/18749.

304.07.2012 tarihli ve 6353 say1l Kanun'un 34' üncü maddesiyle, bu maddede yer alan “yedi yıl” ibaresi "sekiz yıl" şeklinde değiştirilmiştir. 
Türkiye'de Mekânsal Erişilebilirliği Sınırlayan Altyapı Eksikliklerinin Engelli İstihdamına Etkisi

Hizmetinde Yer Alan Otobüsler ile İlgili İçişleri Bakanlığı Genelgesi ile belediyelerin işletilmesi ve denetimi altındaki sınıf 1 ve sınıf 2 otobüslerin teknik şartlara uygun duruma getirilmesi, şehir içi toplu ulaşımda kullanılan otobüs durak yerleri ve engellilerin iniş ve binişlerinin kolaylaştıracak fiziksel şartların sağlanması, otobüslerin içindeki bilgilendirmeyi sağlayan sesli ve görsel uyarı sistemlerinin eklenmesi gerekliliği hükme bağlanmıştır. 2012 tarih ve 6353 sayılı Kanun ile 5378 sayılı Kanun'un geçici 2. ve 3. maddesindeki yedi yıllık süre sekiz yıl şeklinde yeniden düzenlenmiştir (RG: 12.07.2012/ 28351). 6353 sayılı Kanun'da erişilebilirlik standartlarının uygulanmasının izlenmesi ve denetiminin her ilde Aile ve Sosyal Politikalar, İçişleri, Çevre ve Şehircilik, Ulaştırma, Denizcilik ve Haberleşme Bakanlıkları ile engellilerle ilgili konfederasyonların temsilcilerinden oluşan bir komisyon tarafından yapılması, eksiklerin tamamlaması için 8 yıllık sürenin bitiminden itibaren iki yılı geçmemek üzere ek süre verilebileceği ifade edilmiştir. 2013 sayılı Erişilebilirlik İzleme ve Denetleme Yönetmeliği’nde engellilerin ulaşılabilirliği açısından tüm yapıların ve toplu taşıma araçlarının erişilebilirliğini izleme ve denetime amacıyla komisyonların teşkili, çalışma usul ve esasları, Kanun ile belirtilen yükümlülüklerin yerine getirilmesi için ek süre verilmesi, idari para cezalarının uygulanmasına ve genel bütçeye gelir kaydedilen idari para cezası tutarlarının kullanılması hususları ele alınmıştır (RG: 20.07.2013/28713; Tiyek vd., 2016: 230-232).

2005 tarih ve 5393 sayılı Belediye Kanunu'nun hemşeri hukuku başlıklı 13. maddesinde herkesin ikamet ettiği beldenin hemşerisi olduğu, tüm hemşerilerin belediyenin kararlarına ve hizmetlerine katılma, faaliyetleri hakkında bilgilendirilme ve yardımlardan yararlanma haklarına sahip oldukları belirtilmiştir. Aynı maddede belediyelere hemşeriler arasındaki kültürel ve sosyal ilişkileri geliştirme görevi yüklenmiştir (RG: 13.07.2005/ 25874). Söz konusu kanun hükmüne göre hemşerilerin, belediyelerin sunacağı hizmetler ve yardımlardan eşit oranda yararlanabilmeleri bakımından, belediyelerin hizmet sunumu ve yardım faaliyetlerinde engellileri de gözeten planlamalar yapmalarını gerektirdiği söylenebilir.

Türkiye'de engellilerin mekânsal erişimlerine ilişkin düzenlemeler çalışma yaşamını da kapsamaktadır. 1982 Anayasasında, çalışma ile ilgili hükümleri düzenleyen beşinci bölümde, çalışmanın bir hak olduğu, devletin bu hakkı koruyacak ve herkesin yararlanmasını sağlayacak tedbirleri alacağı ifade edilmiştir (RG: 18.10.1982/ 17863). Bu bağlamda, engellilerin de iş piyasalarında yer almalarının bireysel ve toplumsal refahı artıracağı, istihdam artışının üretkenliği, vergi gelirlerini, sigorta primlerini de artıracağı, buna karşın sosyal yardım harcamalarını düşüreceği ifade edilmiştir. Engellilerin iş piyasasına katılmalarının, kendilerine güvenlerini artıracağı ve kendilerini toplumun yararlı bir parçası olarak hissetmelerini sağlayacağ 1 da belirtilmiştir (Selek Öz ve Orhan, 2012: 38).

Dünyada engellilerin istihdamına yönelik kota sistemi, korumalı işyerleri, kişisel çalışma yöntemi, işverenlerin zorunluluk olmadan engelli istihdamı, evde çalışma, kooperatif çalışma yöntemi, sadece engellilerin çalıştırıldığı seçilmiş işlerde istihdam gibi çeşitli uygulamalara rastlanmaktadır. Türkiye'de ise kota sistemi ve korumalı işyerleri uygulamaları engelli istihdamında ön plana çıkmaktadır (Orhan, 2013: 37-45). Sonuçta, engellilerin insan onuruna yaraşır bir yaşam sürüp, sosyal, kültürel ve ekonomik bakımlardan yaşama tutunabilmeleri için devletin, yerel yönetimlerin, özel sektörün, sivil toplum kuruluşlarının birtakım tedbirler almaları ve bunları hayata geçirmeleri gerektiği söylenebilir. $\mathrm{Bu}$ araştırmada mekânsal erişebilirlik bağlamında engellilerin istihdamı problem edinildiğinden, ulusal düzeyde yapılan düzenlemelerin yerel düzeyde uygulamaya yansıdığı düşüncesinden hareketle belediyeler üzerine yoğunlaşılmıştır. 


\section{II- LITTERATÜR ÖZETİ}

Literatürde, engellilerin istihdamına yönelik uluslararası ve ulusal düzeyde çeşitli araştırmalara yer verildiği görülmektedir. Marumoagae (2012), çalışmasında Güney Afrika'da engellilerin işgücü piyasalarına erişimlerinin kısıtlı olduğu, bu nedenle istihdam koşullarında eşitsizlikler yaşadığını tespit etmiştir. Engellilerin iş gücü piyasasına erişimlerinin kolaylaştırılması için normatif düzenlemelerin yanı sıra yerel yönetimler, özel sektör ve sivil toplum kuruluşları dahil tüm toplum kesimlerinin özel bir çaba göstermeleri gerektiği sonucuna ulaşmıştır.

Çağlar (2012: 541; 587), engellilerin fiziksel, sosyal, ekonomik ve kültürel çevreye, hizmetlere, bilgiye ve iletişime erişebilirliklerini temel insan hakları çerçevesinde ele alarak BM Engelli Hakları Sözleşmesi bağlamında, uluslararası insan hakları düzeninde erişebilirlik kavramını normatif açıdan incelemiş ve Türkiye' deki yasal düzenlemelerle karşılaştırmıştır. Sonuçta, Türkiye'de engellilerin erişilebilirliğini artırmak adına, normatif düzenlemelerin pratikte de uygulanmasını kolaylaştırıcı önlemlerin alınmasının gerektiğini ortaya koymuştur.

Genç ve Çat (2013: 363), Kocaeli Büyükşehir Belediyesi’nin iştiraki olan BELDE- AŞ’ye bağlı Gülen Yüzler Engelliler Mesleki Rehabilitasyon ve İş Merkezi'nde nitel ve nicel bir araştırma yaparak engellilerin sosyal dışlanma riskine karşı korunmaları için, istihdam olanaklarının arttırılması ve mesleki rehabilitasyon imkânları sunularak, topluma entegre edilmeleri üzerinde durmuşlardır. Araştırma sonucunda mesleki rehabilitasyon merkezlerinin korumalı işyerlerinden farklı olarak, engellilerin çalışma yaşamına üretken bir şekilde katılmalarına ve ruhsal açıdan iyileşmelerine katkıda bulunan kuruluşlar olduğunu belirlemişlerdir. İşgücüne katılımın engellilere gelir sağladığı, aile kurmalarına yardımcı olduğu ve sosyal dışlanmayı önleyerek toplumsal entegrasyonu desteklediği yönünde bulgulara ulaşmışlardır.

Abidi ve Sharma (2014: 60-68), Hindistan'daki Engelliler İçin İstihdamın Desteklenmesi Ulusal Merkezi'nin deneyimlerinden yararlanarak sosyal dişlama, fiziksel altyapıya ve bilgiye erişebilirlik açısından değerlendirerek engelliliğin, yoksulluk ve işsizlik ile ilişkisini kurmaya çalışmışlardır. Engellilerin, işsizlik ve yoksullukla mücadelelerinin, toplumsal yaklaşımlarla aşılabileceğine vurgu yaptıkları çalışmalarında, yasal ve politik değişikliklerin yanında, erişilebilirlik kavramına önem verilmesinin ve bu konuda toplumsal farkındalığın arttırılmasının gerekliliği üzerinde durmuşlardır. Engellilik ve yoksulluk döngüsünün kırılabilmesi için eşitsizliklerin çok sektörlü bir yaklaşımla ele alınarak politikalar oluşturulması varmışlardır.

Mamatoğlu (2015: 6), Türkiye'deki engellilerin kamusal alanlarda yaşadıkları sorunlarla ilgili toplumun genel algı düzeyini Aile ve Sosyal Politikalar Bakanlı̆̆g1'nın 2014 yılında gerçekleştirdiği "Türkiye'de Engelliler İçin Erişilebilirlik Projesi” kapsamında incelemiştir. Türkiye'nin 78 ilinden katılan kişilerle, yüz yüze yapılan görüşmelerden elde veriler değerlendirilmiştir. Araştırma sonucunda, Türkiye'deki engellilerin kamusal alanlarda en fazla bina içi ve dışı mekânlarda yeterli önlemler alınmamasından kaynaklanan kamusal alanlara erişimle ilgili sorunlar yaşadıkları tespit edilmiş̧ir.

4 T.C. Aile ve Sosyal Politikalar Bakanlığı’nın adı 2018 yılında yapılan değişiklikle T.C. Aile, Çalışma ve Sosyal Hizmetler Bakanlığı olarak değiştirilmiştir (Bazı Cumhurbaşkanlığı Kararnamelerinde Değişiklik Yapılması Hakkında Cumhurbaşkanlığı Kararnamesi, Kararname Numarası: 15, R.G. 04.08.2018/ 30499). T.C. Aile, Çalışma ve Sosyal Hizmetler Bakanlığı'nın adı ise 2021 yılında yapılan değişiklikle T.C. Aile ve Sosyal Hizmetler Bakanlığı olarak değiştirilmiştir (Aile ve Sosyal Hizmetler Bakanlığı ile Çalışma ve Sosyal Güvenlik Bakanlığının Kurulması ile Kamu Personel İşlemlerinin Yürütülmesine İlişkin Bazı Cumhurbaşkanlığı Kararnamelerinde Değişiklik Yapılmasına Dair Cumhurbaşkanlığı Kararnamesi Kararname Numarası: 73, R.G.21.04.2021/ 31461). 
Türkiye'de Mekânsal Erişilebilirliği Sınırlayan Altyapı Eksikliklerinin Engelli İstihdamına Etkisi

Mussida ve Sciulli (2016: 1-24), engellilerin yaşam koşullarının, onların istihdam olanaklarına erişimleri üzerindeki etkisini Orta ve Doğu Avrupa'da bulunan Polonya, Çekya, Litvanya, Slovakya, Romanya ve Macaristan ülkelerinde yürüttükleri araştırma ile belirlemeye çalışmışlardır. Adı geçen ülkelerde engellilik halinin istihdam olanaklarına erişimi sınırlandırdığını belirlemişlerdir. Aynı zamanda, engellilerin işgücü piyasasına entegrasyonlarının, ülke ekonomilerini desteklemede önemli bir potansiyel olduğunu belirtmişlerdir.

Tiyek ve Diğerleri (2016: 225), Zeytinburnu ilçesinde nicel bir araştırma yaparak engelli bireylerin kent içi erişebilirliklerine ilişkin çalışmalarında, Türkiye'den İstanbul Metropoliten Alanı'ndaki ulaşım altyapısını niceliksel özellikleri ve engellilerin yasal haklarını değerlendirmişlerdir. Araştırma sonucunda, Zeytinburnu ilçesindeki toplu ulaşım sistemlerinde engellilerin erişebilirliğine yönelik düzenlemelerin eksik ve standartlar dışında olduğunu tespit etmişlerdir.

Şat ve Göver (2017: 521; 539), belediyelerin, engellilerin yaşam kalitesini arttırmaya yönelik çalışmalarının etkilerini Çorum ili örneğinde "Çorum Engel Haritası Projesi"nin verilerinden yararlanarak incelemişlerdir. Çalışmalarında, dışsal mekân düzenlemelerinin engellilerin yaşama dahil olma imkânlarını arttırdığına vurgu yapmışlardır. Sonuçta, engellilerin yaşam kalitelerinin artırılabilmesi bakımından Çorum Belediyesi'nin teknik kadrosunun yanında, engellilere yönelik güncel, teknik ve istatistiki çalışmalarının sayısını arttırması gerektiği ve planlamaya ve uygulamaya yönelik personelin engellilerle empati kurmalarının önemi vurgulanmıştır.

Aygün vd., (2018: 20), engelli bireylerin kentsel dış mekânlara erişilebilirliğini Tekirdağ ili Süleymanpaşa ilçesinde gerçekleştirilen gözlemlerle Tekirdağ incelemişlerdir. Kentsel dış mekânlar ile kentsel donatıların engelli bireylere yönelik dış mekân standartlarına uygun olarak tasarlanıp tasarlanmadığını engelli kullanıcıların kentsel alanlara erişimlerinde kentsel alt yapıdan kaynaklanan eksikliklerle karşılaştıkları belirlenmiştir. Araştırmacılar, belirlenen eksiklikleri gidermede "Engelliler İçin Evrensel Standartlar Kılavuzu"nun uygulayıcılar tarafından dikkate alınmasını önermişlerdir.

Literatür değerlendirildiğinde gerek uluslararası gerekse de ulusal düzeyde yapılan araştırma bulgularında engellilerin mekânsal erişimle ilgili çeşitli sorunlarla karşılaştıkları ve bu sorunların da onların istihdam edilebilirliklerini olumsuz yönde etkilediği anlaşılmaktadır. Engellilerin istihdama katılmalarının önündeki mekânsal erişilebilirlikten kaynaklanan eşitsizliklerin ortadan kaldırılmasında, yalnızca yasal düzenlemelerin yeterli olmadığı, bu düzenlemelerin yerel düzeyde karar vericiler ve uygulayıcılar tarafindan hayata geçirilmesinin gerekliliği anlaşılmaktadır. Engellilerin istihdamının onların psikolojileri üzerindeki olumlu etkilerinin yanında, ülke ekonomisi üzerinde de olumlu etkilerinin olacağ 1 görülmektedir. Engellilerin erişilebilirlikle ilgili sorunlarının ortadan kaldırılarak, iş yaşamına eşit oranda katılımlarında, altyapı planlanırken kamu, özel sektör, sivil toplum kuruluşları ve yerel yönetimleri de içine alan çok aktörlü ve engellilerle empati kurabilen yapıların önemli roller üstlenebilecekleri anlaşılmaktadır.

\section{III- YÖNTEM}

Yöntem başlığı altında araştırmanın problemi, soruları, amacı, önemi, kapsamı, sınırlılıkları, deseni, veri toplama yöntemi ve analiz tekniği, araştırmanın geçerliliği ve güvenirliği hakkında bilgi verilmiştir. 


\section{A- Problem ve Araştırma Soruları}

Türkiye’de, mekânsal erişilebilirliği sınırlayan altyapı eksikliklerinin engelli istihdamına etkilerinin belirlenmesi araştırma problemi olarak ele alınmıştır. Araştırma Çanakkale Belediyesi sınırları içerisinde yürütülmüş olup a) Engellilerin mekânsal erişilebilirlik noktasında karşılaştıkları başlıca sorunlar nelerdir? b) Mekânsal erişilebilirliğe ilişkin sorunlar işverenlerin engellilere iş vermeye yönelik tutumlarını nasıl etkilemektedir? sorularına cevap aranmıştır.

\section{B- Amaç ve Önem}

Araştırmada, Türkiye'de mekânsal erişilebilirliği sınırlayan altyapı eksikliklerinin engelli istihdamına etkilerinin belirlenmesi ve bunların çözümüne yönelik öneriler geliştirilmesi amaçlanmıştır. Literatürde engellilerin sosyal yönden dışlandıkları, mekânsal erişilebilirliğin engellileri kapsamaktan uzak olduğu, fiziksel altyap1 eksikliklerinin engelliler için daha önemli bir sorun teşkil ettiği, engelliliğin istihdam olanaklarını olumsuz yönde etkilediği, engellilerin temel haklarından ve özgürlüklerinden mahrum kaldıkları, engellilere yönelik kentsel düzenlemelerin onlarla empati kurulmadan gerçekleştirildiğine yönelik bulgular yer almaktadır. Engelli istihdamını sınırlayan, altyapı eksikliği kaynaklı mekânsal erişilebilirlikle ilgili sorunların hem engelliler hem de engelli istihdam eden işverenler açısından değerlendirmeye tabi tutulması bu araştırmayı önemli kılmaktadır. Çünkü yalnızca belediye, engelli ya da işveren bakış açısından bir değerlendirme yapılması, sorunun tüm boyutlarıyla ortaya konulması ve çözüm üretilmesi bakımından yetersiz kalacaktır.

\section{C- Kapsam ve Sinırlılıklar}

Araştırma, Eliöz, Demir ve Akbuğa (2017: 357)'nın “Engelli Dostu İller Sıralaması” adlı araştırmalarında Türkiye'de 10. sırada gösterdikleri Çanakkale ilini kapsamaktadır. Çanakkale'nin araştırma sahası olarak belirlenmesinde, araştırmacının ikamet ettiği şehir olması ve "Engelli Dostu İller Sıralaması"nda ilk 10'da yer alması etkili olmuştur. Çanakkale'de 11 ilçe ve 12 belediye bulunmaktadır. Araştırma nitel desene göre tasarlandığından, yüz yüze görüşme yöntemiyle veriler toplandığından, zaman ve para kısıtları da dikkate alınarak Çanakkale Belediyesi sınırları içerisindeki engelliler ile engelli çalıştıran işyerleriyle sınırlandırılmıştır.

\section{D- Desen}

Araştırma, nitel araştırma desenlerinden örnek olay araştırması şeklinde tasarlanmıştır. Örnek olay, bir konu, olgu veya problemi anlamak için bir veya birden fazla olay veya kişiler kullanılarak yapılan çalışmalardır. Örnek olay araştırmasında çalışılan öğe bir kişi, sınıf, ofis, okul, fabrika, şehir ya da meslek türü olabilir (Güler vd. 2015: 301-302). Güncel bir olguyu kendi yaşam çerçevesi içinde çalışan, olgu ve içinde bulunduğu içerik arasındaki sınırların kesin hatlarıyla belirgin olmadığı, birden fazla kanıt ve veri kaynağının bulunduğu durumlarda kullanılan görgül bir araştırma desenidir (Yıldırım ve Şimşek, 2016: 289).

\section{E-Veri Toplama Yöntemi ve Analiz Tekniği}

Bu kapsamda, Çanakkale ili merkez ilçedeki mekânsal erişilebilirliği sınırlayan altyapı eksikliklerinin engelli istihdamına etkilerinin belirlenmesine çalışılmıştır. Veriler yüz yüze görüşülerek toplanmıştır. Çanakkale ili merkez ilçedeki engelli ve engelli çalıştırma yükümlügü bulunan işverenler ile görüşmeler yapılmıştır. Merkez ilçede ikamet eden tüm engelli çalışanlar ve engelli çalıştırma yükümlülüğü bulunan işverenlerle görüşülmesi hedeflenmiştir. Ancak, görüşme için ayrılan sürede görüşmeye katılmayı kabul eden engelli çalışanlar ve engelli çalıştırma yükümlüğü bulunan işyerleri ile görüşülmüştür. Araştırma 
Türkiye'de Mekânsal Erişilebilirliği Sınırlayan Altyapı Eksikliklerinin Engelli İstihdamına Etkisi

verilerinin toplanması için ayrılan 17.06.2019-26.08.2019 tarihleri arasında 28 engelli ve 28 işveren olmak üzere toplamda 56 katılımcı ile görüşülmüştür. Görüşmelerde engellilere ve işverenlere ayrı ayrı üçer sorudan oluşan yarı yapılandırılmış görüşme formları ile sorular sorulmuştur. Görüşmeler, engelli bireylerle Sakatlar Konfederasyonu Çanakkale Şubesi aracılığıyla şubenin binasında ve engelli birey çalıștıran işyerlerinde, işverenlerin ise işyerlerinde yapılmıştır. Görüşmelerin her biri yaklaşık olarak 30'ar dakika sürmüştür. Katılımcılardan izin alınarak, görüşmeler not edilerek kayda alınmıştır. Tutulan notlar, Microsoft Office Word programına aktarılarak dokümanlar oluşturulmuştur. Dokümanlar, literatür incelemesi kapsamında belirlenen temalar ve onlara ilișkin alt kodlar halinde kategorize edilmiştir. Ayrıca, araştırma sürecinde belirlenen kodlardan da eklemeler yapılmıştır. Toplanan veriler içerik analizine tabi tutularak çözümlenmiştir. İçerik analizi birbirlerine benzeyen verilerin belirli kavramlar ve temalar çerçevesinde bir araya getirilerek, okuyucunun anlayabileceği bir biçimde düzenlenerek yorumlanmasıdır (Yıldırım ve Şimşek, 2016: 242). İçerik analizi sürecinde kodlamalar cümle düzeyinde gerçekleştirilmiştir. Analizlerde MAXQDA Analytics Pro 18.3.0 Programının demo sürümünden yararlanılmıştır.

\section{F- Geçerlilik ve Güvenilirlik}

Nitel araştırmalar, farklı varsayımlara ve görüşlere dayandığı için değerlendirilmesinde de farklı ölçütler kullanılmaktadır. Bulguların inanılırlık derecesini arttırmak için iç geçerliliğin çeşitli stratejilerle güçlendirilmesi gerekmektedir. Bu stratejiler çoklu ve farklı kaynakları, yöntemleri, araştırmacıları ve teorileri destekleyici kanıtlar oluşturmak için kullanılan üçgenleme, yorumların mülakata katılan veya gözlenen bireyler tarafindan kontrolünün sağlanması, uygulamanın yapıldığı ortamda kalınması, benzer nitelikler taşıyan uzmanların görüşlerinin alınması ve araştırmacının olası ön yargı ve varsayımlarının açıklığa kavuşturulmasıdır. Bulguların tutarlık derecesini içeren güvenilirlik ise araştırmacının çalışmanın temelini oluşturan varsayım ve kuramları açıklaması, verilerin sağlamasının yapılması ve çalışmanın nasıl yapılıp verilere nasıl ulaşıldığının açık ve detaylı olarak tanımlanmasını kapsamaktadır (Merriam, 2018: 227; Creswell, 2016: 251).

Geçerlilik, nitel araştırmalarda bir çalışmanın iyiliği ya da sağlamlığı ile ilgilidir ya da araştırmanın ölçülebilirliğinin değerlendirilmesidir. Her nitel araştırmanın amacı ve yöntemleri geçerliliğin türünü de değiştirmektedir. Bazı nitel araştırmacılar araştırmanın geçerliliğini bütünü ile kanıtlama gereği duymazken bazıları da geçerlilik kavramının yerine kalite, titizlik ve güvenilirlik gibi terimler kullanmışlardır. Geçerlilik farklı araştırmacılar için farklı anlamlar taşıyabilmektedir. Bununla birlikte, geçerliliği kavramsallaştırmada iki temel özelliğe önem verilmektedir. Birincisi araştırmanın profesyonel, doğru ve sistematik olarak, ikincisi ise şeffaf bir şekilde yürütülmesidir. Nitel çalışmada geçerlilik kavramı, incelenmekte olan olgunun doğru bir şekilde temsil edilmesi ve tüm gerçekliğiyle ortaya konulması, olgunun objektif olarak gözlemlenmesi, elde edilen sonuçların bütünlüğünü ve yapı ile veri arasında kurulan bağın doğruluğunu ifade etmektedir (Güçlü, 2019: 393).

Nicel ve nitel araştırmalarda kullanılan geçerlilik kavramları birbirinden farklıdır. Nicel çalışmalarda iç geçerlilik kullanılırken nitel çalışmalarda inandırıcılık dış geçerlilik ise transfer edilebilirlik olarak kullanılmaktadır. Nitel araştırmalarda geçerlik ve güvenirlik kavramları iç geçerlilik-inandırıcılık, dış geçerlilik-aktarılabilirlik/transfer edilebilirlik; iç güvenilirlik-tutarlılık, dış güvenilirlik-teyit edilebilirlik kavramları ile ilișkilendirilmektedir. İnandırıcılık, araştırmacının elde ettiği bulguların gerçekliğiyle, benzer ortamlarda da araştırma sonuçlarının geçerliğiyle, süreçlerin birbirleriyle tutarlılığıyla, verilerin nesnel bir yaklaşımla toplanılıp sunulmasıyla ilgilidir (Yıldırım ve Şimşek, 2016: 277- 283). Araştırma verilerinin engelliler ve engelli çalıştıran işverenlerle yapılan görüşmelerden toplanmış 
olması, görüşülen her bireye ait kimlik ve iletişim bilgilerinin araştırmacıda kayıtlı bulunması, benzer araştırma yapan herkesin bu verilere ulaşma imkânlarının bulunması araştırma bulgularının gerçekliğine delil gösterilebilir. Araştırma bulgularının literatürdeki benzer araştırmaların sonuçlarıyla örtüşmesi benzer ortamlarda sonuçların geçerli olduğunu göstermektedir. Veri toplama ve analiz sürecinde de tutarlı bir yol izlenmiştir. Veriler mümkün olduğunca nesnel ve tarafsız şekilde toplanıp sunulmaya çalışılmıştır. Nitel araştırmalar olay veya olguları ayrıntılı olarak incelemeye yöneldiklerinden genellenebilirlik kavramı yerine aktarılabilirlik kavramı tercih edilmektedir (Yıldırım ve Şimşek, 2016: 283). $\mathrm{Bu}$ araştırmada aktarılabilirliği sağlamak için izlenen yol, kullanılan yöntem ve analiz tekniği ayrıntılı şekilde anlatılmıştır. Aynı zamanda, araştırmanın tutarlılığını arttırmak için dışarıdan bir gözle bakılmaya çalışılarak, verilerin toplanması, kodlanması ve analiz süreçlerinde tutarlı davranılmaya özen gösterilmiştir. Araştırmada ulaşılan sonuçlar, araştırma verileri ve bulgularıyla teyit edilerek okuyucuya mantıklı bir şekilde açıklanmıştır.

\section{IV-BULGULAR}

Analize ilk olarak MAXQDA Analytics Pro 18 programının "Görsel Araçlar Penceresindeki Kod Matris Tarayıcısı" sekmesi kullanılarak çalışmanın tema ve alt kodları belirtilmiştir. Araştırmaya katılan engelli çalışanları temsilen " $E$ " kodu, işverenleri temsilen de "K" kodu kullanılmıştır.

Şekil 4.1.'de engelli ve işverenler açısından belirlenen temalar ve alt kodlar yer almaktadır. Temalar işe alım ve engel düzeyi, avantajlar ve işyerine erişim olarak belirlenmiştir. İşe alım ve engel düzeyi 6, avantajlar 11, işyerine erişim 11 alt koda ayrılmıştır. Katılımcılar tarafından en çok vurgu yapılan tema işyerine erişim temasıdır. İşyerine erişim temasının altında yaya yolu ve kaldırımlar ve toplu taşıma hizmetlerinden yararlanma ise en çok tekrarlanan alt kodlardır. Avantajlar temasının altında yer alan psikolojik yarar en çok vurgulanan alt kod iken, ikinci sırada da maddi kazanç yer almaktadır. Engel düzeyi ile ilgili tema altında ise en çok fiziksel engel alt kodu tekrarlanmıştır.

İşveren görüşmelerinde engelli çalışanların mekânsal erişilebilirliği ile ilgili görüşmelerde İşe Alım ve Engel Düzeyi, Avantajlar, İşyerine Erişim temaları belirlenmiştir. İşe alım ve engel düzeyi teması diyabet, görme engeli, fiziksel engel, psikolojik engel olarak alt kodlara ayrılmıştır. İşverenlerin, istihdam önceliğinde görme (4 kişi) ve fiziksel (4 kişi) engellileri daha çok tercih ettikleri anlaşılmaktadır.

"Hizmet sektöründe faaliyet gösterdiğimiz için ne kadar engel durumuna dikkat etmiyoruz desek de etmemiz gerekiyor. Bizim iş kolundaki işleri yerine getirebilecek kişileri elbette ki tercih etmeye çalışlyoruz. Özellikle ikili ilişkiler önemli olduğu için psikolojik engeli olan bireylerden seçmemeye çalışıyoruz. Duruma göre de otelimiz içerisinde departman değişikliği yapıyoruz. Örneğin ayağında engeli olan bir çalışanımız ütü odasında ayaklarını yormadan çalışlyor. Veya tek gözünde görme engeli olan bir çalışanımız evrak işlerinde zorlanacağı iç̧in temizlik işlerinde çalışıyor.” (K.1)

“Bizim şirketimiz alan olarak biraz tehlikeli ve teknik bilgiye dayall hizmet veriyor... Elektrikle uğraşmak, direklere tırmanmak veya saha personeli olarak görev yapmak engelli vatandaşlarımıza pek uygun değil. TEDAŞ’ın verdiği EKAT adında bir yetkinlik belgesi bulunuyor. Bu belgeyi almak için de yeterli fizik ve ruh sağlığına sahip olmak gerekiyor. $O$ yüzden de sahip olduğu engeli kurumumuza ulaşmasında sorun oluşturabilecek kişiler bu belgeyi alamadığı için bu türde kişilerle pek çalışma firsatı bulamadık. Ancak merkezimizde ofis, sekreterlik, santral, temizlik gibi alanlarda çalışan engelli statüsündeki kişiler mevcut." “.... Bu yüzden de mümkün olduğunca engel düzeyi düşük olan kişileri istihdam ediyoruz. 
Türkiye'de Mekânsal Erişilebilirliği Sınırlayan Altyapı Eksikliklerinin Engelli İstihdamına Etkisi

Örneğin; tek elinde bir engeli olan çalışanımız var, diyabet hastası bir çalışanımız var. Bu ve bunun gibi engeller herhangi bir olumsuzluk doğurmuyor bizim için.” (K.2)

Şekil 4.1. Engelli ve İşverenler Açısından Belirlenen Temalar

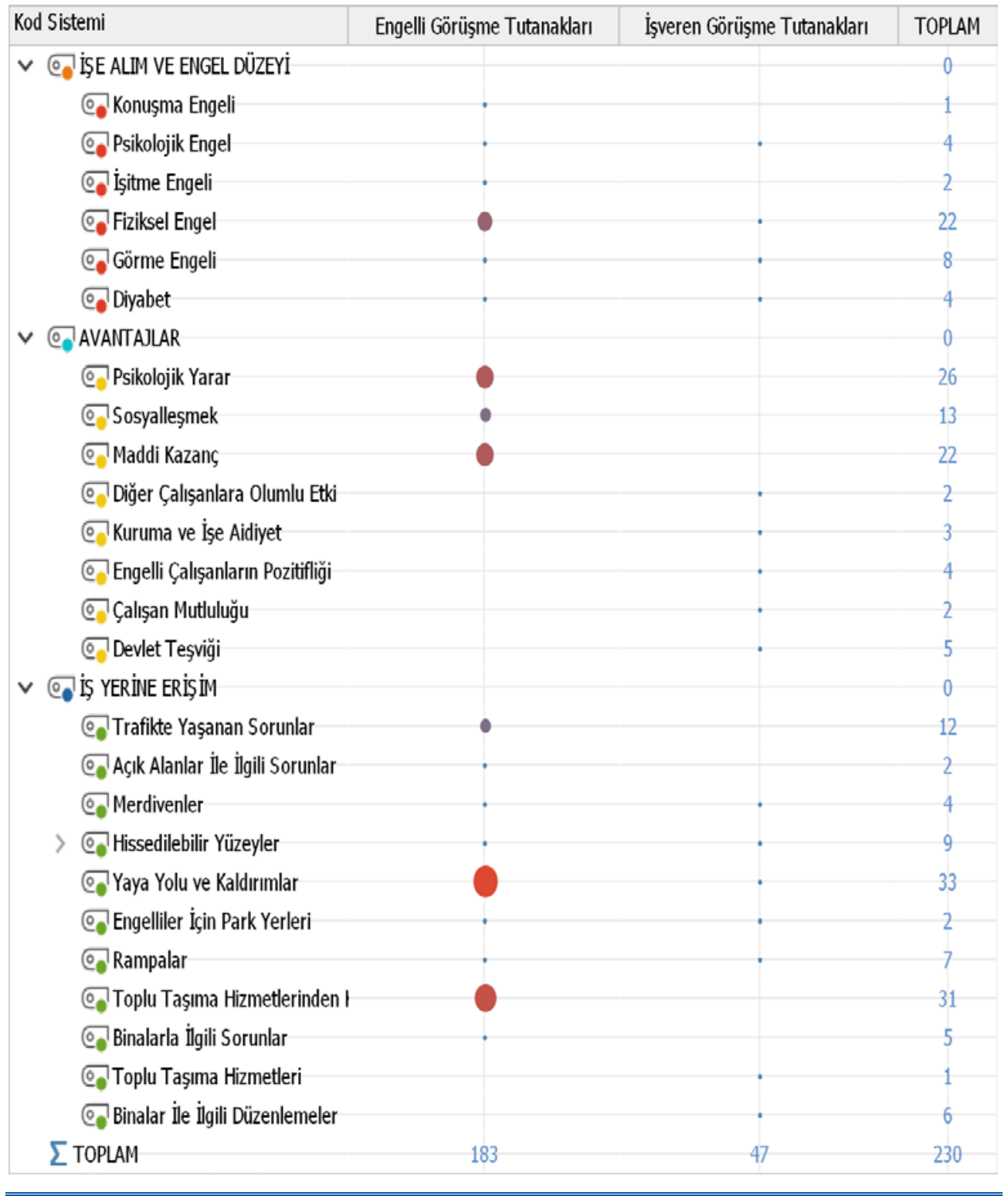

"Bizim için öncelik psikolojik bir engelinin bulunmamasıdır. Böyle bir durumda ona uygun bir işletme olmadı̆̆ımız açık. Hizmet sektörünün gerekliliği öncelikle iyi iletişim kurabilmektir ve bunu sağlamayan çalışan almamız söz konusu değil. Ayrıca müşteriyle iletişim kuracă̆ için mümkün olduğunca genel geçer özürler bizim için uygun oluyor.” (K.3)

"Engelli çalışanların birçoğunu bahçede çalıştırdı̆̆ımız için fiziki olarak çok büyük bir engelinin olması önceliğimiz konumunda. Bu mantıkla düşünülünce görme engelli bir birey 
de bizlere pek uygun değil. Ayrıca burada her düzeyde eğitim veriyoruz ve birçok çocukla günümüzü geçiriyoruz. O yüzden ağır ilaçlar kullanan, psikolojik sorunlarl ve engeli bulunan birini düşünmemiz dahi zor olur...” (K. 7)

"Benim için tek sorun görme engeli. Gözü gören herkes için benim firmamda iş mevcut. Normalde 4 çalışan olması lazım ancak çalışacak adam bulamıyorum. " (K. 11)

"Fiziken engelli olan depo şefimiz bile var, ancak fizik olarak aktif olması bizler için çok önemli. Bunun dışında da belirli bir seviyenin üzerinde olan psikolojik engellerden kaçınmaya çalışıyoruz." (K. 18)

"Evrak işinin çokluğundan dolayı görme engelli, vatandaşla yüz yüze çalışıldı̆̆ı için de psikolojik engelli bireylerin bizlerle çalışabilmesi pek mümkün görünmüyor.” (K. 22)

“Bizim anlaşmamı gereği \%60’ın altında olmak zorunda. Şoförlük yapması gerektiği için de görme ve duyma engelli bireylerin çalışması imkânsız, fiziki engeli olan bireylerin de zor olduğunu söyleyebilirim." (K. 26)

Avantajlar teması altında devlet teşviki (5 kişi) engelli işçi çalıştırmanın en önemli nedeni olarak vurgulanmıştır. İşverenler, engellilerin çalışmalarına pozitif bakmakta (4 kişi) ve performanslarını beğenmektedirler. Aynı zamanda, kuruma ve işe aidiyet (3 kişi) açısından da olumlu görüşe sahiptirler. Çalışan mutluluğu (2 kişi) ve diğer çalışanlara olumlu etkisi (2 kişi) ise öne çıkan diğer konulardır.

“Bu konuda devlet teşviki bulunuyor, ancak biz bunu pek önemsemiyoruz. Tabi ki alt sinıra uymamı gerekiyor, ancak kurum politikamıza uygun şekilde eleman alımı veya istihdam sağllyoruz. Şu anda, otelimizde 5 adet engelli kadrosundan çalışanımız var, ancak bunun dışında da normal statüden aldığımız ve bizimle çalışan engelli bireyler bulunuyor. Bunun dışında, avantaj olarak mutluluğu örnek verebilirim. Engelli çalışanlarımız genelde pozitif oluyorlar ve çalışma arkadaşlarıla araları iyi oluyor. Bunun dışında da aidiyet duyguları çok gelişmiş oluyor. Kuruma, biz müdürlerine ve çalışma arkadaşlarına işi benimseme noktasında örnek teşkil ediyorlar. Diğer çalışanları da bu konuda etkilediklerini düşünüyorum. Açıkçası o yüzden bu durum tamamen bizim avantajımıza.” (K.1)

"Devletimiz bu konuda belirli zorunluluklar getiriyor. Zorunlulukların yanında elbette ki belirli teşvikler de bulunuyor. Biz, bu teşvik ve imkânlardan faydalanmak için genelde IŞKUR aracılı̆̆ıyla eleman alımı yapıyoruz. Toplamda ilçeler de dahil 10 kişiye yakın bir istihdamımız var. Bu konuda sosyal güvenlik priminin (ki bu rakam hemen hemen asgari ücretin dörtte birine denk geliyor) hazine tarafindan ödenmesi güzel ve teşvik edici bir uygulama. Çalışma ortamındaki duruma gelirsem, ben pek bir fark olduğunu gözlemlemedim. O gözle bakmadiğım için normal çalışan nasıl çalışıyorsa, engelli çalışanlar da aynı durumda çalışlyor.” (K.2)

"Belirli sayıda engelli birey de çalıştırmak zorundayız. Tabii ki bunun için hazine tarafindan sağlanan prim desteği bulunuyor. Diğer anlamda düşünürsek ben engelli çalışanımızdan oldukça memnunum. Bugüne kadar bir kez olsun suratını asık görmedim. Bazen bu kadar pozitif olmayı nasıl başarlyor diye düşünüyorum. Ayrıca, verilen görevi en iyi şekilde yapmaya çalışlyor. Mutfakta ondan yana en ufak bir sorun olduğunu hatırlamıyorum.” (K.3)

“...Sadece primlerin ödenmesinin dışında maaş yardımlarının da sürekli hale gelmesi gerekiyor...” (K.4)

"Ben, engellilerin pozitifliğini çok seviyorum. Daima güler yüzlü oluyorlar ve bizlere de örnek oluyorlar. O yüzden, ekip arkadaşı olarak büyük keyif alıyorum.” (K. 13) 
Türkiye'de Mekânsal Erişilebilirliği Sınırlayan Altyapı Eksikliklerinin Engelli İstihdamına Etkisi

“Genel olarak fark yok, ama birkaç çalışanım titiz, dikkatli, detaycı ve işe sahip çıkan özelliklere sahipti. Tabi ki devlet teşvikini de unutmamak gerekiyor.” (K. 18)

"Çok pozitif oluyorlar, işlerini gerçekten iyi yaptıklarına inanıyorum, işe bağlılıkları yüksek ve bana göre normal çalışanlara göre fazlaca hirslı oluyorlar.” (K. 19)

"Genelde sorumluluk sahibi oluyorlar. İş saatlerine uyan, pozitif ve verilen işi anında yapmalart ise diğer avantajlar olarak sayılabilir.” (K. 22)

"Engelli çalışandan yana yüzümün pek güldüğü söylenemez. O yüzden bu zamana kadar bir avantaj görmek nasip olmadl." (K. 25)

"Bence gayet disiplinli oluyorlar. İşi benimseme, görevini laylğıyla yapma, aidiyet duygusunun fazlalığ ve vefa duygularının gelişmiş olması en büyük artıları. Ayrıca, bu yolu açan devlet teşvikleri de en büyük avantajlardan biri olarak sayılabilir.” (K. 26)

"Çalışan kişinin genel özellikleri etkili olduğu için bu soruyu cevaplamak zor. Devletin sağladiğı teşvikten başka bugüne kadar herhangi bir avantaj görmedim.” (K. 28)

İşyerine erişim temasında, işverenler, engelli bireylerin başta kendi kurum binaları olmak üzere binalarla ilgili düzenlemelerin (6 kişi) en büyük sorun olduğunu vurgulamışlardır. Hissedilebilir yüzeylerle (3 kişi) ilgili eksikliklere de vurgu yapıldı̆̆ı görülmektedir. İşverenlere göre, hissedilebilir yüzeylerle ilgili bilgilendirme ve işaretlemelerin olmaması erişilebilirlik konusundaki sorunların başında yer almaktadır. Özellikle, işverenlerin en çok tercih ettiği engelli işçi grubunun görme ve fiziksel engellilerden oluştuğu göz önüne alındığında, engelli çalıştıran işverenler bakımından, merdivenler ve hissedilebilir yüzeylerle ilgili bilgilendirme ve işaretlemeler konularındaki eksikliklerin, engellilerin mekânsal erişilebilirliğini kısıtlayan başlıca etken olduğu söylenebilir. Rampalar (2 kişi), merdivenler (2 kişi), toplu taşıma hizmetleri (1 kişi), engelli park yerleri (1 kişi), yaya yolu ve kaldırımlar (1 kişi) işverenlere göre, engellilerin mekânsal erişimde karşılaştıkları diğer sorunlardır.

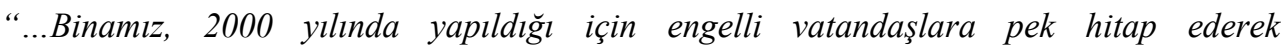
tasarlanmamış. Biz, günümüzde bazı çalışmalar yapmaya çalışıyoruz, fakat istenen düzeyden uzak. Ülkemizde ve şehrimizde de bizler gibi yeniden yapılanma konusunda girişimler bulunuyor. Kaтu kurumlarında bu düzenlemelerin zorunlu olması güzel bir uygulama. Belediyeler, biraz yapmak için yapıyor gibi geliyor bana. Çünkü engelliler için yapılan işler ve hizmetler nokta atışı yapılmıyor. Park yerleri çizilmiyor, çizilse de vatandaş buna dikkat etmiyor. Toplu taşıma engelliler için uygun değil. Bilgilendirme işaretleri ve levhaları pek kullanılamıyor ve uygun yerlerde değiller. Bu gibi sorunların çözülmesi elbette ki engelli vatandaşlarımız açısından hayati önem taşımaktadır." (K.2)

"Bizden bağımsız çevre şartları düşünüldügünde, engellilere dönük pek bir şey olduğu söylenemez. Ön kaldırımımızda sarı renkteki engelli yürüyüş düzeneği var, ancak arka tarafta bulunmuyor. Daha önce bunu dile getirdik, ancak herhangi bir şey yapılmadl. İskele tarafinda ışıklarda engelliler için birkaç işaret var, ama bu çevrede maalesef çok az. $O$ yüzden ben engelliler için olan uygulamaların mümkün olduğunca arttırlması gerektiğine inaniyorum." (K.3)

“...çevre şartları düşünülürse; yol kenarı bir yer olduğu için kaldırım burada mevcut değil. Işıklandırma ise bana göre yetersiz. Işılklar çevresinde levha ve işaretlemeye ihtiyaç var. Ben otobüse binmiyorum, ancak önümüzden geçen toplu taşımalara baktığımda ise hepsi küçük araçlar ve engellilere hitap ettiği söylemez." (K.4) 
“...Firma çevresinde zaten herhangi bir hizmet görmek imkânsız. Çünkü otoyol yanı. Şehir içinde ise gözüme en çok çarpan yaya geçitleri oluyor. Bana göre kaldırıma bağlandıkları yerlerin kırpılması gerekiyor, çünkü çok dikler. Toplu taşıma ise yeterli gibi, özellikle yeni araçlar sayesinde. Bunun dışında uyarı levhaları, bir de sarı renkteki şeritler çoğaltılabilir." (K.5)

“...Yaya geçitleri özensiz, toplu taşıma istenen seviyeden uzak, kaldırımların birçoğu bozuk, sarı şeritlerin çoğunluğu eski ve yıpratılmış halde...” (K. 8)

“...Bizim dışımızda düşünecek olursam; toplu taşıma kullanmadığım için bu konuda pek fikrim yok, ama kaldırımlar rezalet durumda. Sarı şeritler yola çok yakın ve bir anda kesiliyor. Uyarıcı levha veya tabela daha önce hiç görmedim zaten.” (K. 11)

“...Mesela toplu taşıma ve kaldırımlar bana göre gayet başarıll. Ancak yaya geçitleri, sarı şeritler, merdivenler ve levhalandırma kesinlikle yeterli değil.” (K.12)

“...Sadece işaretlendirme çalışmaları üzerinde durulabilir, çünkü çok fazla olduğu söylenemez.” (K. 13)

“...Otoparklar, giriş rampaları, toplu taşımalar ve yaya geçitleri gayet iyi durumda. Bir tek kaldırımlara ayrı bir özen gösterilmesi gerekiyor. Ayrıca levha veya işaretlendirme daha önce hiç görmedim.” (K. 14)

“...Merdivenler oldukça dik, engelli otopark yerleri çok az. Engelliler için açık alanlar düzenlenmeli. Toplu taşıma ise genel haliyle iyi durumda denebilir.” (K. 17)

“...Çanakkale genelinde ise toplu taşımalar ve kaldırımların engellilere uygun olduğunu düşünüyorum. Ancak yaya geçitleri, sart şeritler, tabela ve levhalar ve de üst geçitler maalesef uygun değil." (K. 26)

Engelli çalışanlarla yapılan görüşmelerden elde edilen veriler de İşe Alım ve Engel Düzeyi, Avantajlar, İşyerine Erişim temaları altında kategorize edilmiştir. Görüşülen engellilerin 18'i fiziksel, 4'ügörme engelli, 3’ü ise diyabet rahatsızlığı bulunan kişilerdir. Bunların dışında,1 konuşma, 1 işitme ve 1 de psikolojik engelli çalışanla görüşülmüştür. Engelli bireyler "Avantaj" teması altında en çok psikolojik yarar (26 kişi), maddi kazanç (22 kişi) ve sosyalleşme (13 kişi), kodlarına vurgu yapmışlardır. Kendilerini psikolojik olarak iyi ve faydalı hisseden engellilerin işle ilgili motivasyonlarının ve performanslarının yüksek olduğu anlaşılmaktadır.

"Benim gibi görme engelli vatandaşların en büyük sorunu sosyalleşmek oluyor. Birçok görme engelli vatandaş bırakın çalışmayı evden dahi dışarı çıkamamakta. Bu yüzden benim için en büyük artısı elbette ki sosyalleşmek ve insan içine karışmak. Bunun dışında bir işe yaradığımı hissetmek benim için diğer artılar." (E.3)

"Hayatımın hemen hemen hiçbir döneminde kolumu kaybedene kadar sosyalleşme sorunu yaşamadım. Ancak kolumu iş kazası sonucu kaybedince inanılmaz büyük bir özgüven kaybı yaşadım. Tekrar çalı̧̧maya başlayınca yeniden sosyalleştim, kolum yok diye kendimi işe yaramaz hissederken birçok işe yaradı̆̆ımı fark ettim.” (E.7)

"Bizler gibi tekerlekli sandalyedeki engellilerin masraflarl gerçekten fazla oluyor. Belediye bir takım ihtiyaç ve sandalyeleri karşılasa da bizlerin isteklerine uygun değiller ve eski teknolojiler. Bugün bir akülü sandalye almak dünya para. O yüzden çalışmam sayesinde kazandığım parayı kendime harcayabiliyorum.” (E.9) 
Türkiye'de Mekânsal Erişilebilirliği Sınırlayan Altyapı Eksikliklerinin Engelli İstihdamına Etkisi

“...Zorlandiğım zamanlar oluyor, ancak tedavimin devamlılı̆̆ için çalışmam gerekiyor. Diyabet ilaçları ve iğnelerinin bazıları dönem dönem masraflı olabiliyor. Malulen de emekli edilmedim o yüzden çalışmak zorundayım. ”(E.11)

"Benim için dünyanın merkezinde insanlar bulunuyor. Insanlarla iç içe olduğum her an mutluyum. İş hayatı da bana bu imkânı fazlasılla sağllyor. Pek tabi para kazanmak da işimin büyük bir artısl oluyor." (E. 13)

“...İnsanlar içinde bir yaşantı sürdürmek engelli olmadığımızı hissettiriyor, özgüvenimizi artırtyor."(E.14)

"Sosyalleşmek bizler için büyük bir önem taşıyor. Çünkü evde olduğunuz her an kafanızda birçok kuruntu yapıyorsunuz ve kafayı yeme eşiğine geliyorsunuz. İş hayatı, aslında bana bir tedavi merkezi gibi. İs arkadaşlarım sayesinde birçok takıntımdan kurtuldum diyebilirim." (E.15)

"Benim gözümden ilk avantajı tabi ki psikolojik destek oluyor. Insanlarla sürekli beraber olmak engelimin olduğunu bana unutturuyor. Zaten engelliniz doğuştan değilse bu psikolojik destek sizin için daha önemli bir hal alıyor. Benim için en büyük avantajı böyle açıklayabilirim.” (E.17)

“...En büyük avantaj tabi ki geçimimi sürdürebilmek. Engelli olsanız da olmasanız da belli bir paraya ihtiyacınız var.” (E.18)

“...Herkeste olduğu gibi ilk avantaj tabi ki maddi imkân sağlanması. Bunun yanında, uyum sorununu atlatıyoruz. Kendi açımdan bakarsam en büyük sıkıntım topluma karışmaktı. Çünkü üzerinizde bir bask oluyor. Veya böyle düşünüyorsunuz. Ama iş hayatına girmemiz bu düşünceleri aşmamızı să̆lıyor. ”(E.21)

“...Yürümede sıkıntı çekiyorum, o yüzden herkes bana bakıyormuş gibi geliyordu. Ama çalışma hayatına başlayınca, aslında böyle bir şeyin olmadığını çok net anladım. Aslında terapi gibi bir yararı oldu bana. Maddi açıdan bakarsak, tabi ki birinci önceliğim maddi kazanç olur. Hayatımı devam ettirmek için gerekli parayı kazanmam gerekiyordu. "(E. 24)

"İşyerine Erişim" teması altında engelli çalışanların en çok belirttikleri kodlar yaya yolu ve kaldırımlar (32 kişi), toplu taşıma hizmetlerinden kaynaklı sorunlar (31 kişi) ve trafikte yaşanan sorunlar (12 kişi) olarak sıralanmaktadır. İşverenler açısından işyerine erişimi en çok etkileyen unsur binalara ilgili düzenlemeler (6 kişi) iken, engelli çalışanlar için en büyük sorun yaya yolu ve kaldırımlardır. Binalarla ilgili sorunlar (5 kişi), rampalar (5 kişi), hissedilebilir yüzeyler (3 kişi), açık alanlarla ilgili sorunlar (2 kişi), merdivenler (2 kişi), engelliler için park yerleri (1 kişi) de bahsedilen diğer kodlardır. Katılımcıların konu ile ilgili görüşleri şu şekildedir:

“...Elektrikli bisikletimle gelirken kaldırımlarda sorun yaşıorum. Girişlerin dik olmasılla birlikte dükkanlar tarafindan gereğinden fazla işgal edilme durumlarl mevcut. Bunun dışında, araçlar hemen kaldırım girişlerine park ediyor. Diğer yandan da, özellikle birçok işletme ve kurumun giriş kapllarının dar olduğunu söyleyebilirim. ”(E.1)

“...Çanakkale denildiği zaman, kaldırımlardaki sorunları karşısına koymak gerekiyor. Çünkü ilin en büyük sorunu açık ara kaldırımlardır. Girişleri yüksek, yüzeyleri eğimli ve kaldırım taşları bir yüksek bir alçak konumda. Bir de bana göre toplu taşımadaki engelli araçlarının çoğaltılması gerekiyor. ”(E.4) 
"İşe ilk başladı̆̆ım zamanlar otobüsle işe gidip geliyordum, ancak bu noktada yaşadı̆̆ım gecikmeler ve sıkıntılar yüzünden işten çıkarılma eşiğine geldim. Otobüsle işe gelip giderken yaşadığım en büyük sıkıntı otobüs içlerinin dar olmasıydı. Benim 1 kolum yok ve tutunmakta, ayakta durmakta zorlanıyorum. Belirli güzergâhlarda sadece ufak araçlar kullanıldığ için de insanlar yer vermediğinde zorluk çekiyorum. O yüzden birçok defa otobüs dolu diye insanların yer vermeyeceğini düşünerek binmekten korkup otobüse binmemişimdir. ”(E.7)

“...Sadece kış aylarında, özellikle kar vb. yağış olduğunda binanın önündeki rampa çok kaygan oluyor. Daha önce onu düzelttirmek için birkaç girişimimiz oldu, ancak önümüzdeki kaldırımdan dolay istediğimiz meyil verilemedi.”(E.9)

“...Yaya geçitlerinin kaldırımlara bağlandı̆̆ yerler yer yer fazla dik ve işletmeler kaldırımları gerçekten fazlaca meşgul ediyor. Bir de büyükşehirlerde kırmızı ışılkların sesli olduğunu duydum. Bu durumun Çanakkale'de de yaygınlaşması en büyük dileğim. ”(E.12)

“...Fiziksel engelliyim. Kolum yok. Normal zamanlarda toplu taşımalarda bazen sikıntı yaşlyorum. Onun nedeni de sert otobüs kullanıyor şoförlerimiz. Otobüsler genelde dolu olduğu için yer bulamıyorum, ayakta dikilmek zorunda kallyorum. Ani frenlerde veya keskin dönüşlerde bu da insanların üzerine yıkılmama neden oluyor tabi. Toplu taşımaların daha sakin kullanılması benim gibi engelliler açısından iyi olabilir. ”(E.18)

“...Durakta bekliyorsunuz şoförler bazen sizi görmezden geliyorlar. Sirf inip rampayı açmamak için. Bu kadar şeyin yanında bir de kaldırımlar var. Kaldırımlar bırakın engelli vatandaşı, engelsiz vatandaşın yürüyebileceği durumda değil. Kaldırım ortasına tabela koymuşlar."(E.19)

"Servis olmadı̆̆ı için halk otobüslerini kullanıyorum. Görme engelli olduğum için bu konuda fazla şikâyetçiyim. Şimdi bir de yaya geçitlerini her yerde kapattılar. Zaten kaldırımlarda sıkıntı çekiyoruz bir de en baştan diğer başa yürümemiz gerekiyor karşlya geçebilmek için. Yaya geçitlerini kapatmışlar tamam ama oraya uyarıcı bir şey koymamışlar. Bizler belli yerleri ezberleyerek gidiyoruz, siz orayı kapattı̆̆ınızı belli etmezseniz ben bilemem. En büyük şikâyetçi olduğum nokta burası. Bir de kaldırımların ortasına tabela koymaktan vazgeçmemiz gerekiyor. Sarı şeritler bir santim yanından geçiyor zaten çarpmamak mümkün değil. Bu konulara biraz daha önem verilmesi lazım.”(E. 21)

“...Yayalar için yanan yeşil ışık süresi çok klsa. Yaya geçitlerini birçok yerde kapattılar mesela bu da beni zorluyor.”(E.22)

“...Elektrikli bisikletim var. Bu tip araçlar için ayrılmış bir yol olmadığ iç̧in bazen kaldırımdan gitmek zorunda kalıyoruz. Yollarımız dar. Sürekli ezilme tehlikesi var. Kordondaki yolları döşeme taş yapmışlar mesela. Oradaki yaya geçidinden her geçişimde devrilme tehlikesi yaşıyorum. Kaldırımlardaki rampalar çoğu yerde dik. Bu da benim için büyük zorluk.”(E. 23)

"Servisimiz yok. Toplu taşımayı kullanıyordum. Ama ondan da vazgeçtim, çünkü engellilere karşı belli bilinçte olmadıkları için bize tepkileri sürekli olumsuz oluyor. Bu da beni baya etkiliyordu ilk başlarda. Onun yerine kendime akülü sandalye aldım, engelime uygun olan ama bu seferde kaldırımlarda büyük sıkıntılar yaşlyorum. Olmadık yerlerdeki direkler, dik rampalar falan. Özellikle kaldırıma yapılan duraklar sanki kaldırım kullanılmasın diye yapılmış duruyor. Bu beni rahatsız ediyor tabi ki. Ve işyerime ulaşımda da büyük sorun yaşlyorum."(E.26) 
Türkiye'de Mekânsal Erişilebilirliği Sınırlayan Altyapı Eksikliklerinin Engelli İstihdamına Etkisi

Şekil 4.2. Engelli ve İşveren Bakış Açısından Erişilebilirlik ve İstihdam Temalarına İlişkin İki Vaka Modeli

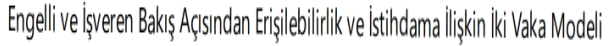

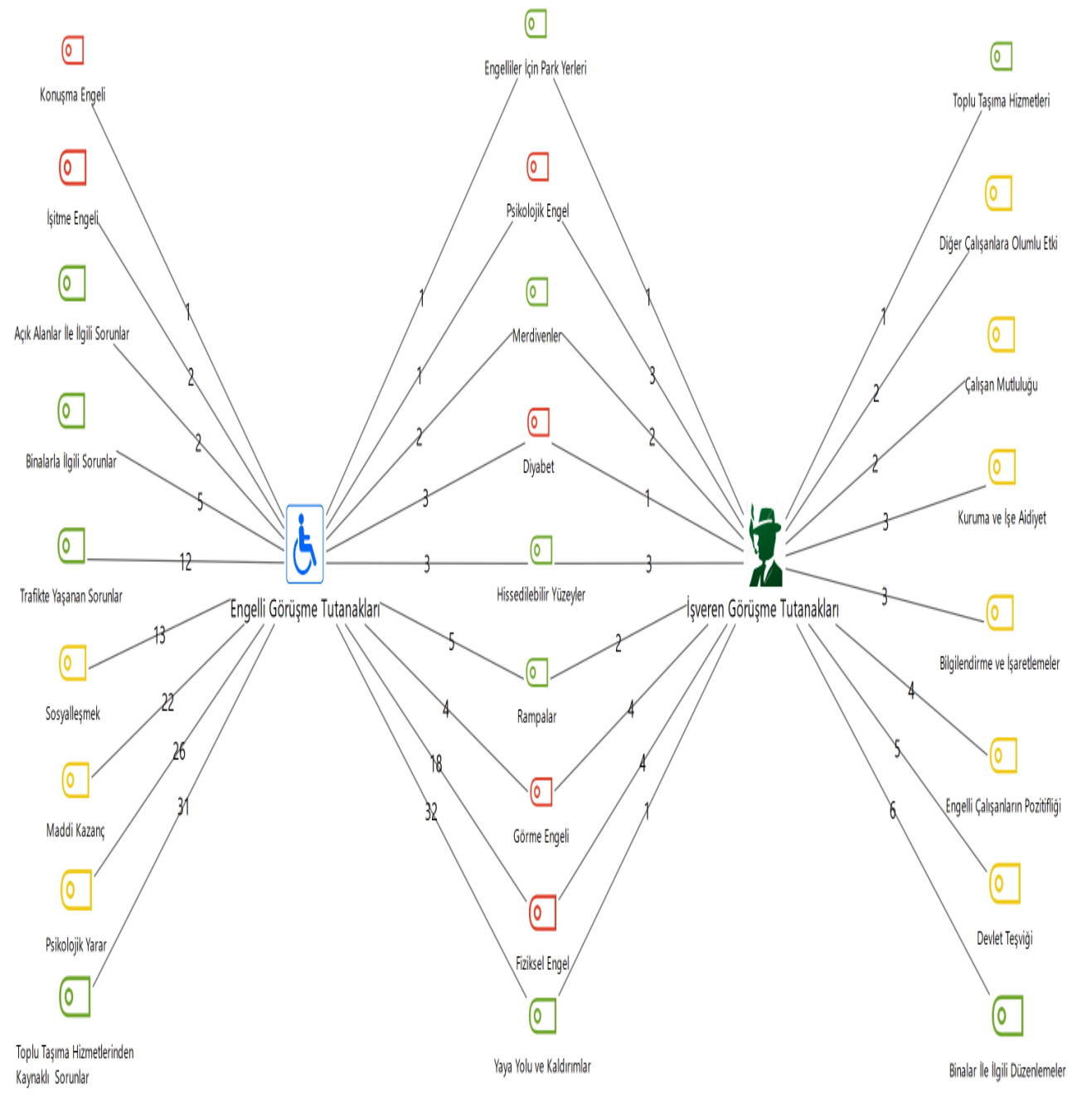

Şekil 4.2'de engellilerin ve işverenlerin bakış açısıyla erişilebilirlik ve istihdama ilişkin görüşler iki vaka modeli ile sabit bir mesafede karşılaştırılmıştır. İki vaka modelinde belirlenen kodların her birinin vakalara göre ne kadar tekrarlandıkları ve bunların gruplar arasında nasıl bir dağılım gösterdikleri gözlenebilmektedir. Bu modelde, iki belge, belge grupları veya belge ve belge gruplarının karışını karşılaştırmak mümkündür (bkz. www.maxqda.com, 2021). Şekil 4.2'de, her iki belge grubunda tekrarlanan ifadeler, ortak kodlar şeklinde, orta kısımda gösterilmiştir. Engelli görüşme tutanakları ve işveren görüşme tutanaklarından ortadaki kodlara giden çizgilerin üzerindeki sayılar ortak kodların her iki belge grubunda tekrarlanma sıklığını göstermektedir. Buna göre, engelli istihdamında erişilebilirlikle ilgili olarak en fazla vurgu yapılan ortak kodlar sırasıyla "yaya yolu ve kaldırımlar" 33 kez, "rampalar" 7 kez, "hissedilebilir yüzeyler" 6 kez, "merdivenler" 4 kez, "engelliler için park yeri”" 1 tekrar şeklinde sıralanmaktadır. 
Şekil 4.2'nin solunda, engelli görüşme tutanaklarında engellilerin işverenlerden farklı olarak vurgu yaptıkları kodlar yer almaktadır. Buna göre, engellilerin erişilebilirlik kapsamında en fazla vurgu yaptıkları kodlar sırasıyla "toplu taşıma hizmetlerinden kaynaklanan sorunlar" 31 tekrar, "trafikte yaşanan sorunlar" 12 tekrar, "binalarla ilgili sorunlar" 5 tekrar, "açık alanlarla ilgili sorunlar" şeklinde sıralanmaktadır. Şekil 4.2'nin sağında ise, işveren görüşme tutanaklarında, işverenlerin engellilerden farklı olarak vurgu yaptıkları kodlar yer almaktadır. İşverenlerin, engellilerin işlerine erişimleri kapsamında en fazla vurgu yaptıkları kodlar sırasıyla "binalarla ilgili düzenlemeler" 6 tekrar, "bilgilendirme ve işaretlemeler" 4 tekrar, "toplu taşıma hizmetleri" 1 tekrar şeklinde sıralanmaktadır.

\section{SONUÇ}

Araştırmada Türkiye'de mekânsal erişilebilirliği sınırlayan altyapı eksikliklerinin engelli istihdamına etkilerinin belirlenmesi amaçlanmıştır. Bu kapsamda a) Engellilerin mekânsal erişilebilirlik noktasında karşılaştıkları başlıca sorunlar nelerdir? b) Mekânsal erişilebilirliğe ilişskin sorunlar işverenlerin engellilere iş vermeye yönelik tutumlarını nasıl etkilemektedir? sorularına cevap aranmıştır.

Bulgular bağlamında engellilerin mekânsal erişilebilirlik noktasında karşılaştıkları sorunlar önem sırasına göre "yaya yolu ve kaldırımlar-33 tekrar", "toplu taşıma hizmetlerinden kaynaklı sorunlar-32 tekrar", "trafikte yaşanan sorunlar-12 tekrar”, "binalarla ilgili düzenlemeler/sorunlar-11 tekrar”, "rampalar-7 tekrar”, "hissedilebilir yüzeyler-6 tekrar”, "merdivenler-4 tekrar", "bilgilendirme ve işaretlemeler-3 tekrar", "açık alanlarla ilgili sorunlar-2 tekrar”, "engelliler için park yeri-2 tekrar" şeklinde sıralanmaktadır. Kentsel alanlar tüm bireyler göz önünde bulundurularak tasarlanmalıdır. Bu noktada araştırma bulgularının, literatürdeki çalışmaların sonuçlarıyla paralellik gösterdiği söylenebilir. Çalışmalarda, engellilerin mekânsal erişilebilirlik noktasında çeşitli sorunlarla karşılaştıkları ve bu sorunlar nedeniyle çalışma yaşamına diğer toplum kesimleriyle eşit oranda katılamadıkları belirtilmiştir. Engellilerin, istihdama katılmalarının önündeki mekânsal erişilebilirlik kaynaklı eşitsizliklerin ortadan kaldırılmasında, yalnızca yasal düzenlemelerin yeterli olmadığı, bu düzenlemelerin yerel düzeyde karar vericiler ve uygulayıcılar tarafından hayata geçirilmesinin gerekliliği vurgulanmıştır. Engellilerin istihdamının onların psikolojileri üzerindeki olumlu etkilerinin yanında, ülke ekonomisi üzerinde de olumlu etkilerine değinilmiştir. Engellilerin erişilebilirlikle ilgili sorunlarının ortadan kaldırılarak, iş yaşamına eşit oranda katılımlarında, altyapı planlanırken kamu, özel sektör, sivil toplum kuruluşları ve yerel yönetimleri de içine alan çok aktörlü ve engellilerle empati kurabilen yapıların önemli roller üstlenebileceklerine dikkat çekilmiştir. $\mathrm{Bu}$ araştırmada ise, engellilerle ve işverenlerle görüşme yöntemiyle nitel bir araştırma gerçekleştirilerek, engellilerin işgücü piyasasına katılımlarının önündeki mekânsal erişilebilirlik kaynaklı sorunların belirlenmesine, bunların çözümüne yönelik merkezi ve yerel karar vericilere yol gösterebilecek veriler sunulmasına çalışılmıştır.

Mekânsal erişilebilirliğe ilişkin sorunların, işverenlerin engellilere iş vermeye yönelik tutumlarını nasıl etkilediği araştırma kapsamında cevap aranan ikinci sorudur. İşverenleri engelli istihdamı konusunda en çok endişelendiren husus bina ve işyerlerinin engellileri gözeterek tasarlanmaması, cadde ve engelliler için bilgilendirmelerin ve işaretlemelerin yetersizliği, rampalar, hissedilebilir yüzeyler, merdivenler, toplu taşıma ve engelli park yerlerinin uluslararası standartlara göre tasarlanmamış olması gibi nedenlerle işe aldıkları engellilerin işyerine gelip gelemeyecekleri konusundaki düşünceleridir. Diğer yandan, engelli istihdam eden işverenlere sağlanan devlet teşviki, engelli çalışanların pozitiflikleri, kuruma aidiyetleri ve işlerine gösterdikleri özen, mutlu çalışanlar olmaları hasebiyle diğer 
Türkiye'de Mekânsal Erişilebilirliği Sınırlayan Altyapı Eksikliklerinin Engelli İstihdamına Etkisi

çalışanlar üzerindeki olumlu etkileri işverenleri engelli çalıştırmaya teşvik eden başlıca nedenlerdir.

Nitel bir araştırma deseni şeklinde tasarlanması nedeniyle, çalışmanın Çanakkale merkez ilçedeki engelli çalışanlar ve engelli çalıştıran işverenlerle sınırlandırılması araştırmanın zayıf yönüdür. Diğer yandan, engelliler ve işverenlerle yüz yüze yapılan derinlemesine görüşmeler, gözlemler ve alan notlarından hareketle verilerin toplanması, verilerin içerik analizi tekniğiyle çözümlenip, şekiller ve haritalarla görselleştirilerek aktarılması araştırmanın güçlü yönleri olarak değerlendirilebilir. Gelecekte, yeterli mali kaynak sağlanması halinde, Marmara Bölgesi, diğer bölgeler ya da tüm iller bazında bir araştırma tasarlanarak, engellilerin istihdamı konusunda karşılaşılan mekânsal erişilebilirlik kaynaklı sorunların, illere ve bölgelere göre farklılaşıp farklılaşmadığının belirlenmesi hususunda daha kapsamlı verilere ulaşılması potansiyeli bulunmaktadır.

Çanakkale merkez ilçede belediye tarafından mekânsal erişilebilirliği artırmaya yönelik bazı altyapı hizmetlerinin sağlanmaya çalışıldığı belirlenmiştir. Bununla birlikte, engelli çalışanların ve engellilere işverenlerin, Çanakkale Belediyesi'nin mekânsal erişilebilirliğe yönelik hizmetlerini yetersiz buldukları anlaşılmıştır. Mekânsal erişilebilirliği sınırlandıran altyapı eksiklikleri ise engelli istihdamı üzerinde olumsuz etkide bulunmaktadır. İşverenler, çalışanlarının zamanında işbaşında bulunmasını arzu etmekte, ancak yaya yolu ve kaldırımların, toplu taşıma hizmetlerinin, bina ve işyerlerinin engellileri gözetmeyen bir anlayışla tasarlanması, rampalar, merdivenler, hissedilebilir yüzeylerle ilgili sorunlar işverenlerin engelli istihdam etme konusundaki görüşlerini olumsuz yönde etkilemektedir. Çalışma hakkı anayasal bir hak olup, devletin ve yerel yönetimlerin her yurttaşın bu haktan eşit şekilde yararlanması için gerekli tedbirleri alması gerekmektedir. Bu noktada, merkezi hükümete düşen görev, uluslararası anlaşmalar çerçevesinde yapılan yasal düzenlemelerin merkezi yönetimin taşra teşkilatı ve yerel yönetimlerce uygulanmasına yönelik maddi destekleri artırmak, yapılan çalışmaların uluslararası ve ulusal standartlara uygunluğunu denetlemek, eksiklikleri gidermeye yönelik tedbirleri almaktır. Yerel yönetimlere düşen görev ise, mekânsal erişilebilirliği sınırlayan altyapı eksikliklerini gidermeye yönelik planlama yapmak ve bunları en kısa sürede hayata geçirmektir. Özel sektör kuruluşları, imkanları dahilinde engellileri istihdam ederek, sivil toplum kuruluşları ise engellilerin istihdam haklarını savunarak, toplumda engellilerin istihdamına yönelik toplumsal farkındalık yaratmaya çalışarak, mekânsal erişilebilirlik kaynaklı engelli istihdamı önündeki engellerin ortadan kaldırılması konusunda merkezi yönetim politikalarına destek sunabilirler. Bu bağlamda, araştırma bulgularının, Çanakkale özelinde mekânsal erişilebilirlik kaynaklı engelli istihdamı önündeki engelleri ortaya koyduğu söylenebilir.

Sonuçta, mekânsal erişilebilirlik engelli istihdamını etkileyen önemli bir faktördür. Engelli yönünden istihdam imkânı bulmak başta hayatlarını sürdürebilmeleri için gereken geliri elde etmeleri, aile kurmaları yanında onların psikolojik olarak kendilerini iyi hissetmelerini de sağlamaktadır. Psikolojik yarar bir yandan kendi kendilerine yetebilme duygusu bir yandan da topluma faydalı olabilme algısı ile birleşmektedir. Ayrıca, engellilerin toplumdan kopmamaları ve sosyalleşebilmeleri için de çalışma hayatına katılmaları önemlidir. İşverenler yönünden ise, engelli çalıştırmanın en iyi tarafı devlet teşvikleridir. Bunun yanında, engelli çalışanların gayretleri, işi benimsemeleri, pozitif tavırları ve diğer çalışanlar üzerindeki olumlu etkilerinin işveren yönünden mekânsal erişilebilirlik kaynaklı işe gelememe endişesini bir dereceye kadar hafiflettiği söylenebilir. Çanakkale Belediyesi açısından da yaya yolları, kaldırımlar, rampalar, duraklar, asansörler, yaya geçitleri, işaretler, bina ve işyerlerine erişim gibi hizmetlerin tüm cadde ve sokaklar genelinde gözden geçirilerek, ulusal standartlara uygun hale getirilmesine yönelik eksiklikleri gidermesi gerekmektedir. 


\section{Kaynakça}

Abidi, J. ve Sharma, D. (2014). Poverty, Disability and Employment: Global Perspectives From the National Centre for Promotion of Employment for Disabled People. Career Development and Transition for Exceptional Individuals. 37(1). 60-68.

Ar, H. ve Uğuz, S. Ç. (2017). Küresel Sürdürülebilir Kalkınma Hedeflerinde Turizmin Rolü: Türkiye Örneği. Uluslararası Sosyal Araştırmalar Dergisi. 10(49). 521-530.

Aygün, E., Korkut, A. ve Kiper, T. (2018). Engelli Bireyler İçin Kentsel Diş Mekânlara Erişilebilirliğin İncelenmesi: Tekirdağ Örneği. ARTIUM Architecture, Urbanism, Design and Construction. 6(2). 20-32.

Bıçkı, D., Yetkin Şale, H. ve Ak D. (2016). Herkes için Erişilebilir Kentler: Muğla Örneği. The Journal of Academic Social Science Studies. 51. 449-470.

Bilsin, E. ve Başbakkal, Z. (2014). Dünyada ve Türkiye'de Engelli Çocuklar. Ege Üniversitesi Hemşirelik Fakültesi Dergisi. 30(2). 65-78.

Birleşmiş Milletler Engellilerin Haklarına İlişkin Sözleşme. R.G. 14.07.2009/ 27288.

Burcu, E. (2006). Özürlülük Kimliği ve Etiketlemenin Kişisel ve Sosyal Söylemleri. Hacettepe Üniversitesi Edebiyat Fakültesi Dergisi. 23(2). 61-83.

Burcu, E. (2011). Türkiye’deki Engelli Bireylere İlişkin Kültürel Tanımlamalar: Ankara Örneği. Hacettepe Üniversitesi Edebiyat Fakültesi Dergisi. 28(1). 37-54.

Creswell, W. J. (2016). Nitel Araştırma Yöntemleri Beş Yaklaşıma Göre Nitel Araştırma ve Araştırma Deseni. Ankara: Siyasal Kitabevi.

Çağlar, S. (2012). Engellilerin Erişilebilirlik Hakk1 ve Türkiye'de Erişebilirlikleri. Ankara Üniversitesi Hukuk Fakültesi Dergisi. 61(2). 541-598.

Eliöz, M., Demir, A. Z. ve Akbuğa, E. (2017). Engelli Dostu İller Sıralaması Çalışması. Akademik Sosyal Araştırmalar Dergisi. 50. 348365.

Erten, Ş. ve Aktel M. (2020). Engellilerin Erişebilirlik Hakkı: Engelsiz Kent Yaklaşımı Çerçevesinde Bir Değerlendirme. Süleyman Demirel Üniversitesi Vizyoner Dergisi 11. 28. 898-912.
Genç, Y. ve Çat, G. (2013). Engellilerin İstihdamı ve Sosyal İçerme İlişkisi. Akademik Incelemeler Dergisi. 8(1). 363-393.

Güçlü, İ. (2019). Sosyal Bilimlerde Nitel Araştırma Yöntemleri Teknik-YaklaşımUygulama. Ankara: Nobel Akademik Yayıncilik.

Güler, A., Halıcıoğlu, M. B. ve Taşğın, S. (2015). Sosyal Bilimlerde Nitel Araștırma. Ankara: Seçkin Yayıncılık.

Güler, M. (2011). Kentsel Haklar, Kapitalizm ve Katılım. Ankara Üniversitesi, SBF Dergisi. 66(1). 49-71.

Goffman, E. (1963). Stigma. London: Penguin Books.

Güler, A., Halıcıoğlu, M. B. ve Taşğın, S. (2015). Sosyal Bilimlerde Nitel Araştırma (2.Bask1). Ankara: Seçkin Yayıncılık.

Mamatoğlu, N. (2015). Türkiye'de Engelliler İçin Ulaşılabilirlik Uygulamaları Algısı. TMMOB Mimarlar Odası Ankara Şubesi Dosya Dergisi. 36(3). 6-13.

Marumoagae, M. C. (2012). Disability Discrimination and the Right of Disabled Persons to Access the Labour Market. Potchefstroom Electronic LawJournal/ Potchefstroomse Elektroniese Regsblad (PER/PELJ). 15(1). 345-365.

Merriam, S. B. (2018). Nitel Araştırma Desen ve Uygulama İçin Bir Rehber. (Çeviri Editörü: Selahattin Turan). (3. Bask1). Ankara: Nobel Yayıncilik.

Mussida, C. a Sciullid. (2016). Disability and Employment Across Central and Eastern European Countries. IZA Journal of Labor\& Development. 5(4). 1-24.

Odabaş-Uslu A. ve Güneş, M. (2017). Engelsiz Kentler-Herkes İçin Erişilebilir Kentler. Uluslararası Peyzaj Mimarliğ A Araştırma Dergisi. 1(2).30-36.

Orhan, S. (2013). Türkiye'de Özürlü Dostu Ístihdam Politikalarl (Durum Analizi ve Öneriler). Ankara: T.C. Çalışma ve Sosyal Güvenlik Bakanlığı, Çalışma ve Sosyal Güvenlik Eğitim ve Araştırma Merkezi Yayınları. 
Türkiye'de Mekânsal Erişilebilirliği Sınırlayan Altyapı Eksikliklerinin Engelli İstihdamına Etkisi

Priestley, M. (2012). Disability. TheStudent's Companion to Social Policy. (Editör: Pete Alcock, Margaret May ve Sharon Wright). 4. Bask1. United Kingdom: Wiley-Blackwell Publishing.

Şat, N. ve Göver T. (2017). Engelliler İçin Belediyelerin Erişilebilirlik Sorumlulukları: Çorum Engel Haritası Projesi. Hitit Üniversitesi Sosyal Bilimler Enstitüsü Dergisi. 10 (1). 521542.

T.C. Anayasas1. RG: 18.10.1982/ 17863. Tiyek, R., Eryiğit, B. H. ve Baş, E. (2016). Engellilerin Erişilebilirlik Sorunu ve TSE Standartları Çerçevesinde Bir Araştırma. Kastamonu Üniversitesi İktisadi ve İdari Bilimler Fakültesi Dergisi. (12). 225-261.

Türk Dil Kurumu [www.tdk.gov.tr]. (Erişim: 30 May1s 2020).

United Nations (1975). Declaration on the Rights of Disabled Persons. General Assembly. Decision of 3449 (XXX).

United Nations (2017). Yeni Kentsel Gündem: HABİTAT III. [http://uploads.habitat3.org/hb3/ NUA-Turkish.pdf]. (Erişim: 25 Mayıs 2020).

World Health Organization (1980). International Classification of Impairments. Disabilities and Handicaps. Switzeland: WHO.

World Health Organization (2001). International Classification of Functioning. Disabilityand Health. Geneva: WHO Library Cataloguing-in-Publication Data.

Yıldırım, A. ve Şimşek, H. (2016). Sosyal Bilimlerde Nitel Araştırma Yöntemleri (10. Bask1). Ankara: Seçkin Yayıncılık.

2006/18 Sayılı Başbakanlık Genelgesi. RG: 12 Temmuz 2006/ 26226.

3194 Sayılı İmar Kanunu. R.G. 09 Mayıs1985/18749.

5378 Sayılı Engelliler Hakkında Kanun. R.G. 07 Temmuz 2005/ 25868.

5393 Sayılı Belediye Kanunu. RG: 13 Temmuz 2005/ 25874.

6353 Sayılı Bazı Kanun ve Kanun Hükmünde Kararnamelerde Değişiklik Yapılmasına Dair Kanun. R.G. 12 Temmuz 2012/ 28351.
Engellilerin Haklarına İlişkin Sözleşme. R.G. 14 Temmuz 2009/ 27288.

Erişilebilirlik İzleme ve Denetleme Yönetmeliği. R.G. 20 Temmuz 2013/ 28713.

[https://www.maxqda.com/help-mx20/maxmaps /two-case-model]. (Erişim: 10 Ocak 2021).

[http://www.mo.org.tr/UIKDocs/kentselsart1.pd f]. (Erişim: 10 Ekim 2020).

[https://rm.coe.int/168071923d].(Erişim: 10.10. 2020). 
